\title{
THE DOCTRINE ON BAPTISM IN THE HAERETICARUM F ABULARUM COMPENDIUM OF THEODORET OF CYRUS
}

\author{
DOI: $10.14232 /$ jp.pgy.2021.3
}

The focus of this paper is on how Theodoret of Cyrus approaches the doctrine concerning the sacrament of baptism in his Haereticarum fabularum compendium ${ }^{374}$. We chose this work of Theodoret, as we deem it to be one of his most important writings in which - in the last stage of his life $e^{375}$ - he summarizes the teachings and history of the earlier and contemporaneous heresies and the orthodox doctrine of the Church.

\section{INTRODUCTION TO THE LIFE AND WORK OF THEODORET OF CYRUS}

Theodoret of Cyrus is one of the most important - but in many aspects neglected theologians of the $5^{\text {th }}$ century. Quasten calls him "the last great theologian of Antioch" ${ }^{376}$. The characterization made by István Pásztori-Kupán is also very expressive:

Theodoret of Cyrus lived during the stormy decades of the third and fourth ecumenical councils of Ephesus (431) and Chalcedon (451), when many important doctrinal questions (including the mode of interpreting Christ as God and man) were in dispute. Being the champion of the so-called Antiochene tradition and an opponent of Cyril, the mighty patriarch of Alexandria, Theodoret left behind a fascinating legacy. His biography shows that he was immersed in the highly tense dogmatic and ecclesiastical-political battles of the fifth century, whilst remaining a truly pious churchman, who had distributed his inheritance to the poor and lived a very modest life even as bishop. The larger part of his extant writings still remains untranslated, which provides a fragmented representation of his thought and has led to his misrepresentation by ancient, medieval and some modern scholars. ${ }^{377}$

He was born in Antioch around the year 393 as a child of a prosperous Antiochene couple who had been childless for many years. There are some details in his Historia Religiosa about the circumstances of his birth. Theodoret received an extensive religious and secular education, and at an early age, he became a lector in the clergy of Antioch. He mentions Diodore of Tarsus and Theodore of Mopsuestia as his teachers. Later he

374 In the text of our paper we will use for it the abbreviation HFC.

375 According to Quasten it was composed about 453. Quasten, Johannes: Patrology III. The Golden Age of Greek Patristic Literature. Christian Classics, Allen (Texas) 1983. 552. (In the followings: Quasten, Johannes: Patrology III.)

376 Quasten, Johannes: Patrology III. 536.

377 Pásztori-Kupán István: Theodoret of Cyrus. Routledge, London 2006. Flap text. 
resided in a monastery, most likely near Apamea, where he lived for about seven years. He left in 423, as he had been appointed Bishop of Cyrus, over a diocese about forty square miles and embracing 800 parishes, but with an insignificant town as its seat. As a bishop, he had many philanthropic and economic activities beside his theological activity:

$>$ he converted more than 1,000 Marcionites in his diocese, also many Arians and Macedonians;

$>$ he withdrew more than 200 copies of Tatian's Diatessaron, in order to introduce the four Gospels in their place;

$>$ he erected churches and supplied them with relics;

$>$ he endeavoured to help people oppressed by taxation;

$>$ he divided his inheritance among the poor;

$>$ he erected baths, bridges, halls, and aqueducts from his episcopal revenues;

$>$ he brought rhetoricians and physicians;

$>$ he sent encouraging letters to the persecuted Christians of Persian Armenia;

$>$ he gave refuge to the Carthaginian Celestiacus who had fled the rule of the Vandals.

The seven years he spent in the monastery before his ordination and the following seven years until the outbreak of the Nestorian controversy were arguably the most peaceful times of his life. The conflict between Cyril of Alexandria and Nestorius of Constantinople brought unfortunate changes in the life of Theodoret. His direct involvement in the debate started in 430 when John of Antioch received the letters of Pope Celestine and Cyril concerning the condemnation of Nestorius by the West and by Cyril's party. The very first and the most famous act written in the defence of Nestorius before the Council of Ephesus was his Refutation of Cyril's Twelve Anathemas, for which he is still criticised. At the Council of Ephesus in 431, Theodoret - alongside 68 bishops (including Alexander of Hierapolis) and the imperial representatives - protested against the opening of the sessions in vain before the arrival of John of Antioch and of the papal legates ${ }^{378}$. After John's arrival, Theodoret joined the Antiochene 'conciliabulum' and adhered to the deposition of Cyril and Memnon. Without going into details that we can otherwise find in the extensive relevant scholarly research, it can be concluded that the ecclesiastical gathering later known as the 'Third Ecumenical Council of Ephesus' never actually took place. ${ }^{379}$ There were two separate priestly meetings, the decisions of which were at first simultaneously validated by the emperor. Later, one of the two was politically supportted, the church being compelled to regard it as the only legitimate one.

378 Hefele, Charles Joseph: A History of the Councils of the Church. tr. by William R. Clark, 5 vol. 3. T. \& T. Clark, Edinburgh 1894-96. 46.

379 Pásztori-Kupán István: Theodoret of Cyrus. Routledge, London 2006. 12. 
After the 'Council of Ephesus', Theodoret assumed the role of the mediator between Antioch and Alexandria. He is a potential author of the famous Formula of Reunion which was already finished in 431, but accepted by the bishops of the two parties only in 433. But the fact that he passed over his hostility towards the bishops of Alexandria and corresponded with them (especially with Cyril) in order to establish the union of the Church did not have the expected results: he was condemned by the Latrocinium in 449 - without a trial and without any chance of defending himself. The last and ultimate humiliation happened at the eighth session of the Council of Chalcedon: the cost of his acceptance as an orthodox teacher was the personal anathema against Nestorius.

We hardly know anything about Theodoret's life after Chalcedon. Even the year of his death is still a matter of dispute. We only know that he died sometime between 453 and 466. At the council held under Emperor Justinian in Constantinople 553, he personally and his works "written against true faith and against St. Cyril" (see Canon 13) were condemned.

The time of his baptism could be an interesting fact related to our topic, but based on the accessible sources, we cannot determine it:

\begin{abstract}
We are unaware of the details or the time of Theodoret's baptism. His correspondence does not reveal anything concerning its circumstances. On the one hand, the sequence by which he presents the events in Letter 143 is perhaps too weak a ground to conclude that he was not baptised in infancy, but only after 'having believed': 'For thus I have been made a disciple from the beginning; thus I have believed; thus I was baptised; thus I have preached, thus I have baptised, thus I continue to teach.' On the other hand, the fact that Theodoret was a child offered to God before his conception did not automatically involve his infant baptism. ${ }^{380}$
\end{abstract}

$$
\text { * * * * * } *
$$

Quasten appraises Theodoret as "one of the most successful writers of the Eastern Church" whose "literary bequest has greater variety than that of the other theologians of Antioch" ${ }^{381}$ He composed works in almost all fields of theology. He wrote exegetical explanations to many biblical books, apologetic, dogmatic and controversial works, and his historical works are also renowned. His letters are also precious sources for discovering the characteristics of his theology. However, he did not pretend to be original, his works are of an excellent eloquence and elegant style, written in a perfect, clear and simple Attic Greek. ${ }^{382}$

381 Quasten, Johannes: Patrology III. 538.

382 Quasten, Johannes: Patrology III. 538-39. 
His teaching concerning baptism has only a few presentations. In the monograph written by István Pásztori-Kupán, there is no separate chapter concerning the doctrine on Baptism in Theodoret's interpretation but he frequently quotes passages form Theodoret's writings which deal with some aspects of baptism. There are 4 pages related to the baptismal doctrine by Theodoret in the precious and particularly ample work of Everett Ferguson Baptism in the Early Church, but we think that the teaching of Theodoret concerning baptism deserves more than a few pages long presentation. A quick search through TLG (Thesaurus Linguae Graecae) shows that Theodoret used words originated from the Greek root $\beta \alpha \pi \tau$ at least 339 times, which means that baptism was an important topic in his writings. It is also true that out of these 339 occurrences of the root $\beta \alpha \pi \tau$, many refer to John the Baptist, others are related to the baptism of Jesus, but it is important to show what remains: teaching clearly and truthfully about baptism was an important goal of Theodoret. The most important writings in which he discusses baptism are as follows: Graecarum affectionum curatio, Eranistes, Historia ecclesiastica, Historia religiosa, Epistulae, Commentaria in Isaiam, De sancta Trinitate, De incarnatione Domini, Questiones in Octateuchum, Questiones in libros Regnorum et Paralipomenon, Interpretatio in Psalmos, Explanatio in Canticum Canticorum, Interpretatio in Jeremiam, Interpretatio in Ezechielem, Interpretatio in Danielem, Interpretatio in XII prophetas minores, Interpretatio in XIV epistulas sancti Pauli, Haereticarum fabularum compendium, De providentia orations decem, Ad eos, qui in Euphratesia et Oshroena regione, Syria..., Quod unicus filius sit dominus noster Jesus Christus...

However, in his other works, Theodoret used more expressions to denote baptism, in his HFC he used only words derived from the root $\beta \alpha \pi \tau$. Of the 46 occurrences of

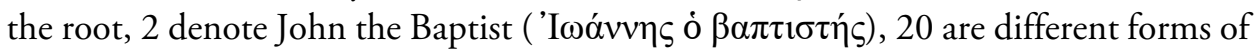
the verb $\beta \alpha \pi \tau i \zeta \omega$, and 24 are forms of the noun $\beta \alpha \dot{\pi} \tau \imath \sigma \mu \alpha$. The root occurs in books $1-4$ and in book 5 as well.

There is a very detailed analysis of the Greek baptismal terminology in the book of J. Ysebaert: Greek baptismal terminology: its origins and early development. However, in part one, which contains the terminology related to washing and immersion, there is no reference to Theodoret, ${ }^{383}$ but it might be useful to have a look at his study because we get an insight into the evolution of baptismal terms through it. The verb $\beta \alpha \pi \tau i \zeta \omega$ is an intensive form of $\beta \alpha \dot{\alpha} \pi \tau \omega$, which primarily means 'to dip', 'to dye', in middle voice 'to dye oneself, or in the Hellenistic Greek 'to draw (water)' ${ }^{384}$ The basic meaning of ' $\beta \alpha \pi \tau i \zeta \omega$ ' is 'to dip' or 'plunge', but it also has the nuance of 'to cause to perish' ${ }^{385} \mathrm{We}$ can see in the texts of Plato or Ebulus that it occasionally occurs in the classical period

383 Ysebaert, Joseph: Greek baptismal terminology: its origins and early development. Dekker \& van de Vegt, Nijmegen 1962. 12-83. (In the following: Ysebaert, Joseph: Greek baptismal terminology: its origins and early development.)

384 Ysebaert, Joseph: Greek baptismal terminology: its origins and early development. 12-13.

385 Ysebaert, Joseph: Greek baptismal terminology: its origins and early development. 13. 
and it is always used metaphorically, "in order to impart a comic accent to the sentence”. ${ }^{386}$ The word ' $\beta \alpha \pi \tau i \zeta \omega$ ' occurs more frequently in the Hellenistic Greek, and was used in both the literal and figurative sense. ${ }^{387}$ In Judaism the verb ' $\beta \alpha \pi \tau i \zeta \omega$ ' and the noun ' $\beta \alpha$ á $\tau \tau \sigma \mu \alpha$ ' became the terminus technicus of the ritual bath that went down by immersion (submersion). ${ }^{388}$ This time, the semantic nuance of 'to cause to perish' disappeared. ${ }^{389}$ The noun ' $\beta \alpha ́ \pi \tau 1 \sigma \mu \alpha$ ' distinguishes the baptism of John and Christian baptism from the Jewish ritual ablutions, referred to as ' $\beta \alpha \pi \tau \imath \sigma \mu o$ í $^{390}$ In the New Testament the words derived from the root $\beta \alpha \pi \tau$ became the terminus technicus

for the baptism of John, for the baptism of Jesus during His public life, and for Christian baptism, although it concurs with the Jewish usage by the absence of the connotation of perishing, is again sharply distinguished by a regular use of the active and passive. ${ }^{391}$

The words ' $\beta \alpha \pi \tau i \zeta \omega$ ' and ' $\beta \alpha \dot{\pi} \tau \tau \sigma \mu \alpha$ ' are termini technici of the baptism of John and Christian baptism in the early Christian literature of the second and third centuries as well. ${ }^{392}$ Ysebaert mentions also that these terms progressively became more and more technical, which made the Christians less conscious of the meaning 'to immerse'. ${ }^{393}$

However, Ysebaert's analysis does not deal with the use of the root ' $\beta \alpha \pi \tau$ ' in the writings of Theodoret of Cyrus, we can see the theological heritage of Theodoret in this research. He inherited a terminology wherein the accent was not on the act of immersion but it rather denoted the whole sacramental chain of events.

\section{THE DOCTRINE ON BAPTISM IN THE $5^{\text {TH }}$ BOOK OF THE HFC}

There are three chapters in book 5 of the HFC which contain important passages concerning baptism: chapter 3, concerning the Holy Spirit, chapter 18, concerning baptism, and chapter 28 , concerning repentance. We will begin our study with chapter 18 , which presents a summary of the author's approach to the theology and practice of baptism. First, let us see the whole text of this chapter: ${ }^{394}$

Greek text from: Theodoretus Cyrensis: Haereticarum fabularum compendium. In: Migne PG 83,512.; English translation from: Ferguson, Everett: Baptism in the Early Church. Eerdmans, Grand Rapids 2009. 715. 
IH. Пврі̀ $\beta \alpha \pi \tau i ́ \sigma \mu \alpha \tau o \zeta$.

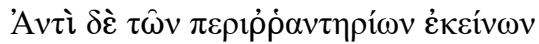

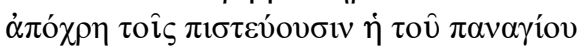
$\beta \alpha \pi \tau i ́ \sigma \mu \alpha \tau o \zeta \delta \omega \rho \varepsilon \alpha ́$. Oủ $\gamma \grave{\alpha} \rho \mu$ óvov $\tau \hat{\omega} v \pi \alpha-$

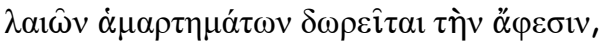
$\dot{\alpha} \lambda \lambda \dot{\alpha} \kappa \alpha \grave{\imath} \tau \grave{\eta े} \nu \dot{\varepsilon} \lambda \pi i \delta \alpha \tau \hat{\omega} v \dot{\varepsilon} \pi \eta \gamma \gamma \varepsilon \lambda \mu \varepsilon \dot{\varepsilon} \nu \omega v$

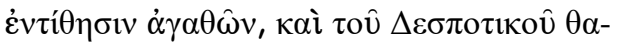

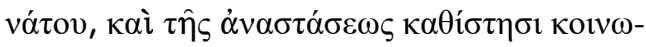

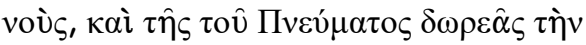

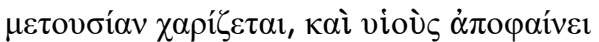

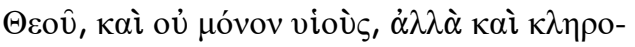
vó Oủ $\gamma \grave{\alpha} \rho, \dot{\omega} \varsigma$ oi $\varphi \rho \varepsilon v o \beta \lambda \alpha \beta \varepsilon i ̂ \varsigma ~ M \varepsilon \sigma \sigma \alpha \lambda$ lavoì

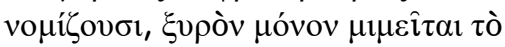
$\beta \alpha ́ \pi \tau 1 \sigma \mu \alpha, \tau \grave{\alpha} \varsigma \pi \rho \gamma \varepsilon \gamma \varepsilon v \eta \mu \varepsilon ́ v \alpha \varsigma$

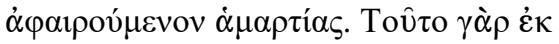

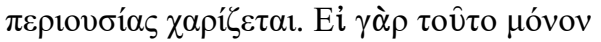

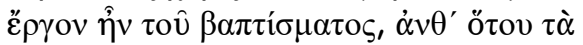

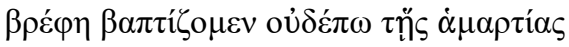

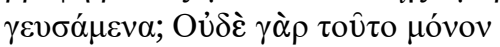

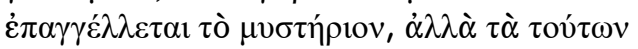

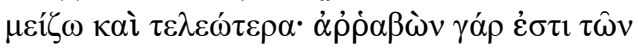
$\mu \varepsilon \lambda \lambda o^{\prime} v \tau \omega \nu \dot{\alpha} \gamma \alpha \theta \hat{\omega} v, \kappa \alpha i ̀ ~ \tau \hat{\eta} \varsigma \dot{\varepsilon} \sigma o \mu \varepsilon^{\prime} v \eta \varsigma$

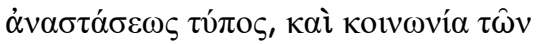

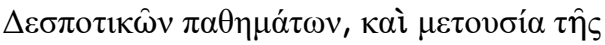
$\Delta \varepsilon \sigma \pi \mathrm{\sigma} \tau \kappa \hat{\eta} \varsigma \dot{\alpha} v \alpha \sigma \tau \alpha \dot{\sigma} \sigma \varepsilon \omega \varsigma, \kappa \alpha i ̀ ~ i \mu \alpha ́ \tau 1 o v$

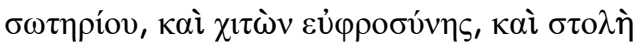

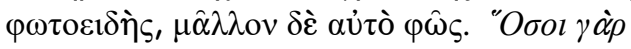
$\varepsilon \dot{\zeta} X \rho \imath \sigma \tau \grave{o v} \dot{\varepsilon} \beta \alpha \pi \tau i \sigma \theta \eta \tau \varepsilon, X \rho l \sigma \tau \grave{v} v \dot{\varepsilon} v \varepsilon \delta \dot{v} \sigma \alpha \sigma \theta \varepsilon$.

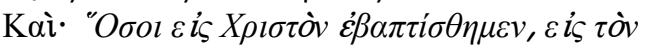

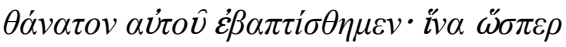

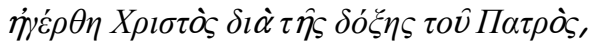

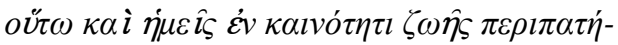

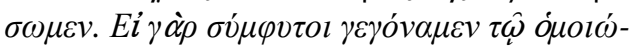

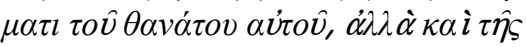
$\dot{\alpha} v \alpha \sigma \tau \dot{\alpha} \sigma \varepsilon \omega \varsigma \dot{\varepsilon} \sigma o ́ \mu \varepsilon \theta \alpha$.

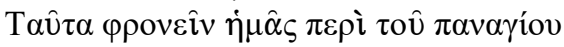

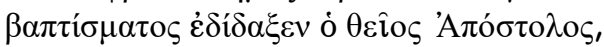

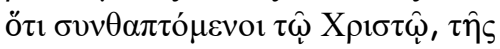

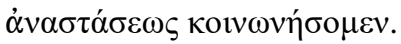

18. Concerning baptism

Instead of the Jews' vessels for sprinkling, there suffices for believers the gift of most holy baptism. It not only gives forgiveness of old sins, but it also inspires the hope of good things promised. It establishes participants of the Lord's death and resurrection; it grants a share of the gift of the Holy Spirit; it declares the sons of God, and not only sons, but also heirs of God and fellow heirs of Christ.

For it is not as the mindless Messalians think that baptism is only a razor removing previous sins. It grants this out of its abundance. For if this was the only work of baptism, why do we baptize infants, who never tasted of sin? The mystery [sacrament] promises not only this but also greater and more perfect things. For it is the down payment of good things to come - a type of the future resurrection, fellowship of the Lord's passion, a sharing of the Lord's resurrection, a garment of salvation, a clothing of joy, a luminous cloak, or rather light itself. For who was baptized into Christ have put on Christ. And: who have been baptized into Christ Jesus were baptized into his death? So as Christ was raised from the dead by the glory of the Father, we too might walk in newness of life. For if we have been united with him in a death like his, we shall certainly be united with him in a resurrection like his.

The divine apostle taught us to think this way about most holy baptism, because having been buries with Christ we shall share in his resurrection. 
After reading this text, we could discern the following elements:

$>$ The all-holy baptism is a gift from God, an expression of his philanthropy;

$>$ It replaces the Jewish cleansing rites. The author summarizes here what he writes about in much more detail in other works. For example, Theodoret writes in his commentary on Psalm 106:

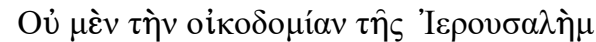
$\pi \rho 0 \sigma \mu \varepsilon \hat{\imath} v \alpha \mathbf{l} \delta \varepsilon \hat{\imath}, \kappa \alpha \tau \grave{\alpha} \tau o \grave{s} \varsigma \mu \hat{v} \theta 0 v \varsigma \tau \hat{\omega} v$

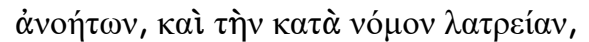

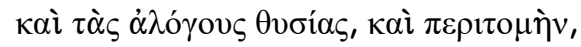

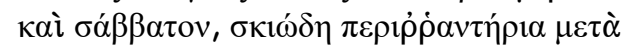

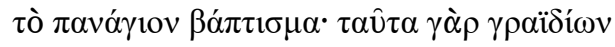
$\mu \varepsilon \theta v o ́ v \tau \omega v \pi \alpha \rho \alpha \lambda \eta \rho \eta ́ \mu \alpha \tau \alpha \cdot \dot{\alpha} \lambda \lambda \grave{\alpha} \kappa \lambda \hat{\eta} \sigma \mathrm{v}$

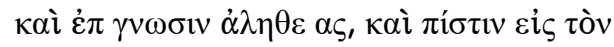

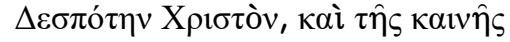

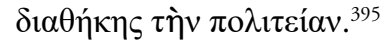

It is, of course, necessary to look forward, not to the rebuilding of Jerusalem, in foolish people's fancies, or to worship by the Law, irrational sacrifices, circumcision, the Sabbath, and shadowy sprinkling after all-holy baptism (these are tipsy old wives' tales), but to vocation and knowledge of truth, faith in Christ the Lord and the way of life of the New Covenant. ${ }^{396}$

Infants also receive it;

$>$ It transmits the remission of former sins;

$>$ It is also the assurance of all gracious future gifts of God (the guarantee of the resurrection; communion with Him, through participation in His passion and resurrection);

$>$ It puts humans in possession of the gifts of the Holy Spirit;

$>$ It turns believers into God's children; this way, they become His heirs and coheirs of Christ.

Before taking a look at the interpretation of modern scholars of Theodoret's text, let us idle upon the expression $\pi \alpha v \alpha \gamma i ́ o v \beta \alpha \pi \tau i ́ \sigma \mu \alpha$. In the Early Church was commonly accepted the use of different epithets expressing increased reverence toward holy persons or things. A search in the TLG for the three most important epithets related to baptism in the early Christian Greek literature (of the first 5 centuries) gives the following result:

395 Theodoretus Cyrensis: Interpretatio in Psalmos. In: Migne PG 80,1733 (43-51).

396 Theodoret of Cyrus: Commentary on Psalms, 73-150 (Hill, Robert tr.). The Catholic University of America, Washington, D.C. 2001. 187. 


\begin{tabular}{|c|c|c|c|}
\hline Author & 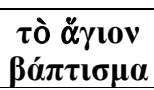 & 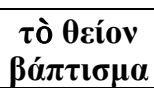 & $\begin{array}{c}\tau o ̀ ~ \pi \alpha v \alpha \gamma i ́ o v \\
\beta \alpha ́ \pi \tau \imath \sigma \mu \alpha\end{array}$ \\
\hline Clemens Romanus & 7 & - & - \\
\hline Melito of Sardis & 1 & - & - \\
\hline Origenes & 3 & 2 & - \\
\hline Athanasius of Alexandria & 22 & - & - \\
\hline Didymus the Blind & 3 & 1 & - \\
\hline Eusebius of Caesarea & 1 & - & - \\
\hline Socrates Scholasticus & - & 1 & - \\
\hline Gregory of Nyssa & 6 & - & - \\
\hline Gregory of Nazianz & 1 & 1 & - \\
\hline Basil of Caesarea & 3 & - & - \\
\hline Acta Conciliorum Oecumenicarum & 18 & 2 & - \\
\hline John Chrysostom & 10 & 3 & 3 \\
\hline Theodoret of Cyrus & 8 & 12 & 38 \\
\hline
\end{tabular}

I think the authors want to underline the divine origin of baptism through these three epithets, and to summarize its effect in the life of baptized believers. This statistic shows that Theodoret surpasses all the other writers in using panegyric epithets in de-

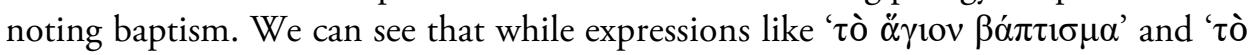

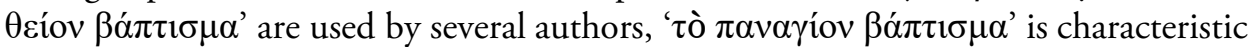
only to the works of Theodoret who might have inherited it from Chrysostom. But in comparison with Chrysostom, we can see that Theodoret used it much more frequently. The use of these panegyric epithets suggests the outstanding importance of baptism in Theodoret's approach.

Everett Ferguson states that Theodoret expresses the same line of thinking as Chrysostom in this chapter which reflects a quite different perspective from that of Theodoret's contemporary, Augustine in North Africa. ${ }^{397}$ Based on this text, researchers argue that Theodoret separates infant baptism from the forgiveness of sins. ${ }^{398}$ In Meyendorff's book we read that according to Theodoret, the remission of sins is only a side effect of baptism, it becomes completely real only in cases of adult baptism. Mark Heim asserts directly that Theodoret denied "that remission of sin was applicable to infant baptism". ${ }^{399}$ But there is a wider and more positive primary meaning to baptism: it is a promise of greater and more perfect gifts than "remission of sins". ${ }^{400}$ In this context

397 Ferguson, Everett: Baptism in the Early Church. Eerdmans, Grand Rapids 2009. 715.

398 Ferguson, Everett: Baptism in the Early Church. Eerdmans, Grand Rapids 2009. 715.; Meyendorff, John: Byzantine Theology: Historical Trends and Doctrinal Themes. Fordham University Press, 1979. 145 .

399 Heim, Mark: The Depth of the Riches: A Trinitarian Theology of Religious Ends. Eerdmans, Grand Rapids 2001. 68.

400 Meyendorff, John: Byzantine Theology. Fordham University Press, 1979. 145-46. 
the Church baptizes children, not to "remit" their yet nonexistent sins, but in order to give them a new and immortal life which their mortal parents are unable to communicate to them. The opposition between the two Adams is seen in terms not of guilt and forgiveness but of death and life. [...] Baptism is the paschal mystery, the "passage". All its ancient forms, and especially the Byzantine, include a renunciation of Satan, a triple immersion as type of death and resurrection, and the positive gift of new life through anointing and Eucharistic communion.

In this perspective, death and mortality are viewed, not so much as retribution for $\sin$ (although they are also a just retribution for personal sins), as means through which the fundamentally unjust "tyranny" of the devil is exercised over mankind after Adam's sin. From this, baptism is a liberation, because it gives access to the new immortal life brought into the world by Christ's Resurrection. The Resurrection delivers men from the fear of death, and, therefore, also from the necessity of struggling for existence. Only in the light of the risen Lord does the Sermon on the Mount acquire its full realism: "Do not be anxious about your life, what you shall eat or what you shall drink, nor about your body, what you shall put on. Is not life more than food, and the body more than clothing?” (Mt 6:25). ${ }^{401}$

Elsewhere, quoting the passage from chapter 18 from the $5^{\text {th }}$ book of the Haereticarum fabularum compendium, concerning the importance and the blessings of baptism, after the quotation, Meyendorff gives the following interpretation of Theodoret's approach:

As a "beginning" and a promise of new life, baptism implies free self-determination and growth. It does not suppress human freedom, but restores it to its original and "natural" form. In the case of infant baptism, this restoration is, of course, only potential, but the sacrament always implies a call to freedom. [...] After baptism, the way toward God is a "synergy" of God's power and free human effort. It is also a liberation from the bonds of Satan - the tyrant and the usurper - signified by the exorcisms which precede the sacrament of baptism itself. ${ }^{402}$

I think that all the above presented interpretations have the seeds of truth, but I find them exaggerating on some occasions. I agree that Theodoret and the Eastern theologians generally present a different approach to baptism from the Western theologians, but I think that the question about separating the forgiveness of sins and baptism is actually more nuanced. First of all, it is important to see that Theodoret wrote his book in an apologetic context. The apologetic approach to the doctrines appears not only in books 1-4 but determines also the tone of book 5 . The author wanted to refute the approach of Messalians in chapter 18 - and therefore he underlined that baptism is not merely like a razor which deletes the sins committed in the past. On the contrary, Theodoret expresses with the Messalian approach that forgiveness of (former) sins is only one benefit of baptism. About the weight of the two aspects of baptism, I think it is inconsiderate to assert that the promise of future grace and blessing is more valuable than that of the forgiveness of sins. It is to be concluded from the text of Theodoret that the author speaks about the double benefit of baptism without superimpos-

401 Meyendorff, John: Byzantine Theology. Fordham University Press, 1979. 146.

402 Meyendorff, John: Byzantine Theology. Fordham University Press, 1979. 194. 


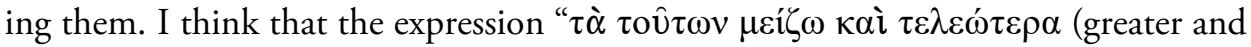
more perfect things)" does not compare the remission of sins and the future gifts of grace by itself but rather expresses that the forgiveness of sins does not stand by itself:

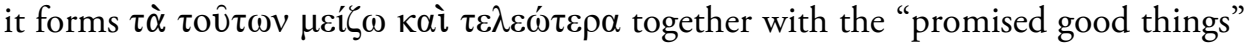
(participation in the Lord's resurrection, the sonship, the gifts of the Spirit, etc.). In his commentary on Psalm 51, Theodoret underlines the importance of baptism in the remission of sins: explaining the prayer of the psalmist "Purify me with hyssop, and I shall be clean; Wash me, and I shall be whiter than snow", he asserts: "only the gift of baptism can achieve this cleansing". ${ }^{403}$

In the context of the doctrine on baptism, Theodoret and all the Eastern theologians generally show, differently from his Western contemporaries, no concept of an inherited Adamic sin. ${ }^{404}$ It is important to see at this point that the absence of a term does not mean compulsorily unbelief concerning the inherited Adamic sin. To be more specific: the absence of the concept of the inherited sin in the Eastern theology is a result of the theological context. In East - due to particular spirituality - such questions did not rise like in Africa Consularis and Rome. The theologians - due to their theological perception of the world and their approach to God and to humans -had other experiences from e.g. Augustine of Hippo. As a result of their experiences, they wrote in another manner. The Eastern (Greek, Scythian, Syrian) theological anthropology could not think about the human world outside of its relation (and its community) to (with) God, while the Western world (see the life-story of Augustine) could imagine humans having a life without God. I think that the Western anthropology was deeply determined by the decadent Roman moral customs, while in the East the Scythian moral ${ }^{405}$ and the Christian monasticism had a stronger influence.

In the first lines of chapter 19, concerning resurrection, there is yet another reference to baptism. It is clear that the main goal of this introduction is to represent a transition between the two chapters, however, it is not only a rhetorical instrument but it also signifies a logical link between the two chapters. There we read the following words:

\begin{tabular}{|c|c|}
\hline 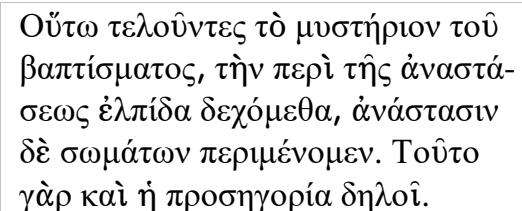 & $\begin{array}{l}\text { This way, ending the mystery of baptism, we } \\
\text { received the hope of resurrection, and we are } \\
\text { waiting for the resurrection of the body. This is } \\
\text { declared (made clear) by the appellation (names) } \\
\text { as well. }{ }^{406}\end{array}$ \\
\hline
\end{tabular}

403 Theodoret of Cyrus: Commentary on Psalms, 1-72 (Hill, Robert tr.). The Catholic University of America, Washington, D.C. 2000. 299.

404 Ferguson, Everett: Baptism in the Early Church. Eerdmans, Grand Rapids 2009. 715.

405 Here I refer to the Scythian customs praised in the works of the ancient historians.

406 Translations with blue letters are my own translations. In other cases I will mention the source of the translations. 
Based on this statement of Theodoret I find the opinion of Meyendorff right who says that baptism is strongly related to the idea of immortality. I would like to mention merely that it is more adequate to speak of the eternal life instead of immortality which is not a 'sui generis' characteristic of the human nature but it is gained through resurrection. In other words, in Eastern theology "baptism brings children into a relationship with Christ, extending to them the promise of eternal life", ${ }^{407}$ without speaking of the annihilation of any kind of inherited sin.

In chapter 3, speaking of dignity and the divine nature of the Holy Spirit, the bishop of Cyrus argues that the Trinitarian baptizing formula is an obvious proof of the divinity of the Holy Spirit: ${ }^{408}$

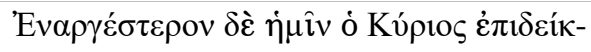

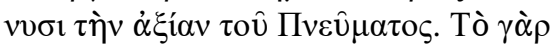

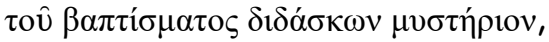

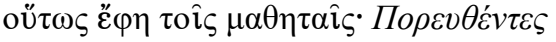
$\mu \alpha \theta \eta \tau \varepsilon \dot{\sigma} \sigma \alpha \tau \varepsilon \pi \dot{\alpha} v \tau \alpha \tau \grave{\alpha} \dot{\varepsilon} \theta v \eta, \beta \alpha \pi \tau i \zeta o v \tau \varepsilon \varsigma$

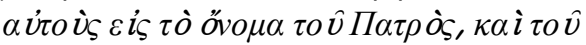

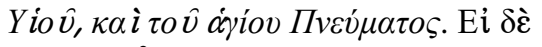

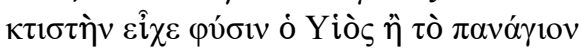

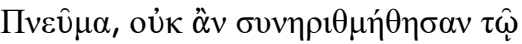

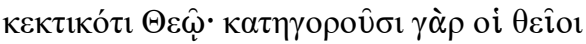
$\lambda$ ófol $\tau \hat{\omega} v \lambda \varepsilon \lambda \alpha \tau \rho \varepsilon v \kappa o ́ \tau \omega \nu \tau \hat{n} \kappa \tau i ́ \sigma \varepsilon ı ~ \pi \alpha \rho \grave{\alpha}$

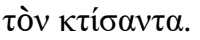

The Lord however shows us the dignity of the Spirit more clearly. Teaching about the mystery of baptism, he told the disciples: "go and make disciples of all nations, baptizing them in the name of the Father and of the Son and of the Holy Spirit". If the Son or the all-holy Spirit had created nature, they could not have been mentioned together with God the Creator. Scilicet the divine words would accuse those who besides the Creator dare to serve creatures as well.

The closer context of this short passage shows the interrelation between baptism and Pneumatology. In the theological framework of Theodoret, baptism is the sign of the reception of the grace of the Holy Spirit. In this context, baptism is the "first step" on the way of becoming the temple of the Holy Spirit (and accordingly, that of God).

A few lines further in the same chapter, there is a passage in which baptism is linked to the Trinitarian approach of creation, and it is called the new creation: ${ }^{409}$

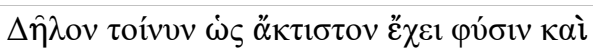

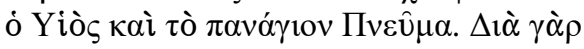

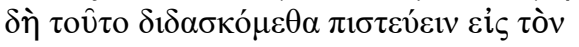

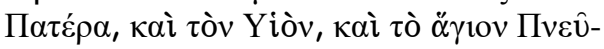

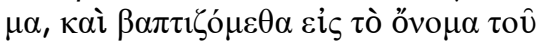

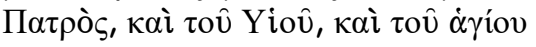

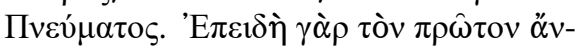

Ergo, it is clear that both the Son and the all-holy Spirit have an uncreated nature. Therefore, we teach that man should believe in the Father, the Son and the Holy Spirit, and [therefore] we baptize in the name of the Father, and of the Son, and of the Holy Spirit. The first man was cre-

407 Hartnup, Karen: 'On the Beliefs of the Greeks': Leo Allatios and Popular Orthodoxy. BRILL, Leiden 2004. 114-115.

408 Theodoretus Cyrensis: Haereticarum fabularum compendium. In: Migne PG 83,457 (22-31).

409 Theodoretus Cyrensis: Haereticarum fabularum compendium. In: Migne PG 83,457 (38-50). 


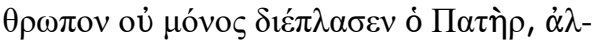

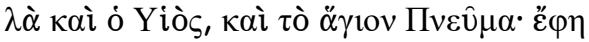

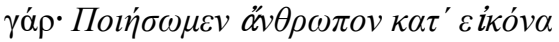

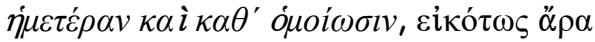

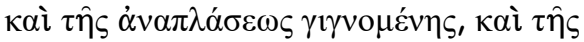

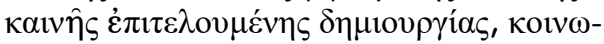

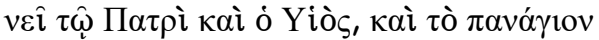

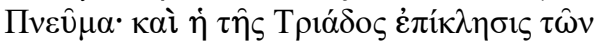

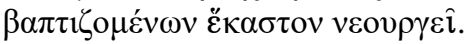

ated not by the Father only but also by the Son and the Holy Spirit. Because he speaks: "Let us make mankind in our image and in our likeness". Therefore, both in the creation which happened and in finishing the new creation the Father reasonably shared with the Son and the all-holy Spirit. And the invocation of the Trinity renews all the baptized.

Because both the Son and the Holy Spirit have uncreated nature, similarly to the Father - it obviously concludes that the creation was the work of the whole Trinity. Theodoret believes that God's saying from Gen 1,26 is the most obvious proof for it: "let us create mankind in our image and in our likeness". If the creation of mankind is the work of the whole Trinity, it is also a matter of necessity that the whole Trinity be active in completing the new creation. It is not the eschatological new creation that is un-

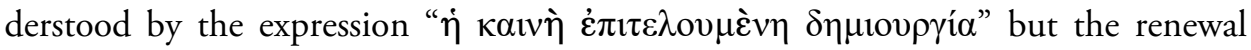
through the Holy Spirit - which is to be gained according to the power of Christ's passion, death and resurrection, and of which baptism is a pledge. The firmest ground of

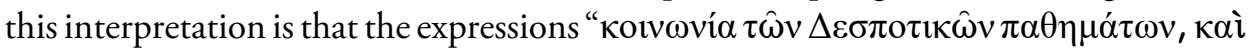

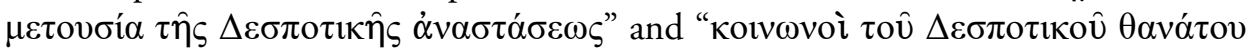
$\kappa \alpha \grave{\imath} \alpha v \alpha \sigma \tau \alpha ́ \sigma \varepsilon \omega \varsigma$ ” play a key-role in chapter 18 . This interpretation is also an indirect manner in the Heidelberg Catechim when it speaks of the benefits of Christ's resurrection. The power of Christ's resurrection "we too are raised up to a new life" (HC 45.) is mentioned as the second benefit which is an obvious reference to the putting on the new man through the Holy Spirit and to the partaking (sharing) in the death and resurrection of the Lord Jesus Christ.

There is a longer passage related to baptism concerning repentance in chapter 28 , dealing with the forgiveness of sins after receiving the grace of the sacrament. In the introduction of this passage, we read that the author wants to refute the doctrinal error of the Novatians: $:^{410}$

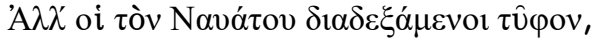

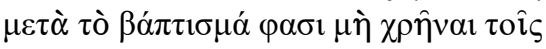

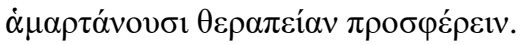
But they who follow the vanity of Novatus say that after baptism it is not necessary to proffer the therapy to those who sin.

Then, after a longer passage which proves that the central message of the Bible is the forgiveness of sins, there begins the explanation of the relationship between baptism and forgiveness of sins happening after being baptized: ${ }^{411}$

410 Theodoretus Cyrensis: Haereticarum fabularum compendium. In: Migne PG 83,549 (10-12).

411 Theodoretus Cyrensis: Haereticarum fabularum compendium. In: Migne PG 83,552-553 (552,7-553,8). 


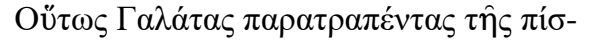

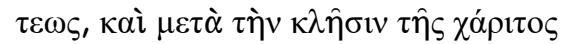

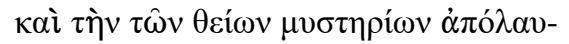

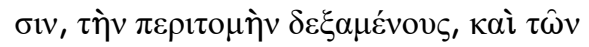

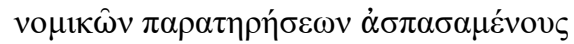

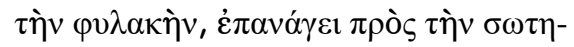

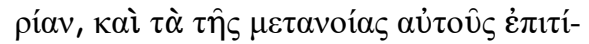

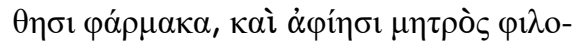

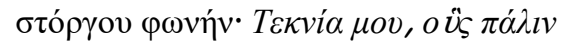

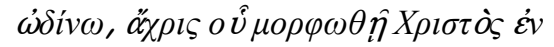
$\dot{v} \mu \hat{i v}$.

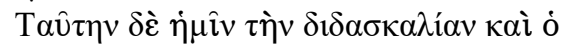

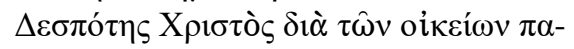

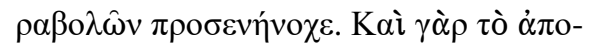

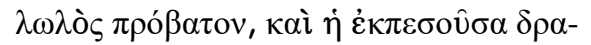

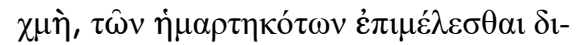

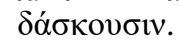

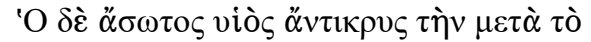

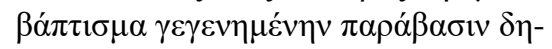

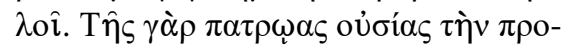

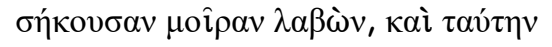

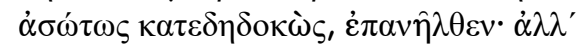

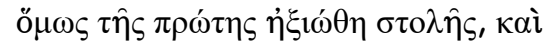

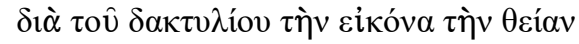

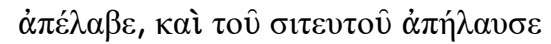

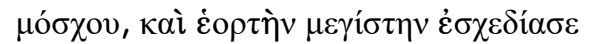
$\tau \hat{\omega} \pi \alpha \tau \rho \dot{.}$.

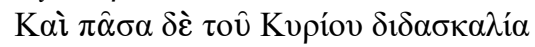
$\kappa \alpha \grave{\imath} \pi \rho \hat{\alpha} \xi 1 \zeta, \tau \grave{\eta} v \tau \hat{\omega} v \dot{\alpha} \mu \alpha \rho \tau \omega \lambda \hat{\omega} v i \alpha \tau-$

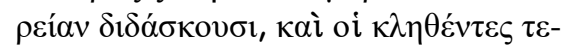

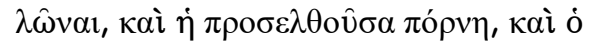

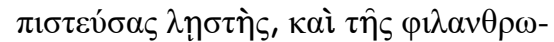

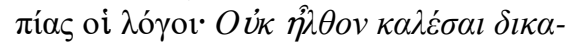

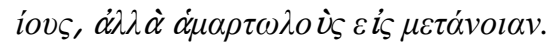

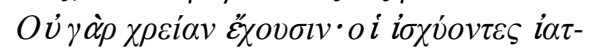

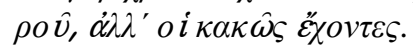

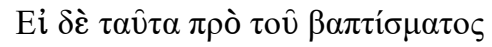

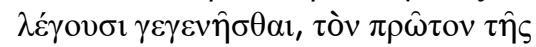

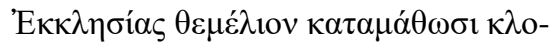

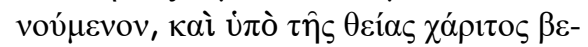

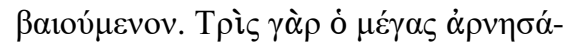

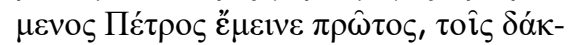

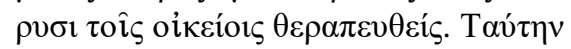

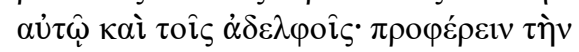

That [happened] to the Galatians who previously accepted the circumcision and who greeted the watch of the observation learned by law when they turned away from faith. But [the apostle], after the call of the grace and the enjoyment of the divine mysteries, led them back to the salvation, proffered them the medicine of conversion, and pardoned them with the words of a loving mother: "My dear children, for whom I am again in the pains of childbirth until Christ is formed in you".

The Lord [Jesus] Christ also presented us this teaching in his own parables.

The parable of the lost sheep and the lost drachma teaches us how men should take care of sinners.

The parable of the prodigal son makes clear what to do in case of transgression after baptism. After having taken his portion of inheritance from the fatherly essence, and after having dissipated it, he came back [to the fatherly house]. But there he received clothes similar to those of his previous dignity, through the finger-ring he put on the divine image, he enjoyed the meat of the fattened calf, and shared the greatest celebration with his father.

Every teaching and deed of the Lord teaches us the healing of sinners. That is [exemplified] through the called tax-collectors, the meretricious woman who came to the Lord, the repenting robber and the words of the philanthropy: "For I have not come to call the righteous but sinners to repentance" and "It is not the healthy who need a doctor but the sick". If they [the Novatians] say that all these happened before baptism, they have to understand that the foundation of the Church felt to the temptation as well, and became firm under the divine grace. The great Peter, after having denied thrice, remained first to be healed with his own tears. This was ordered by the Lord himself, 


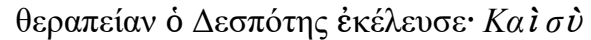

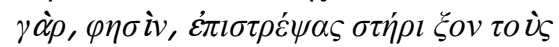
$\dot{\alpha} \delta \varepsilon \lambda \varphi o v ́ \varsigma \sigma o v$.

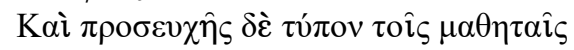

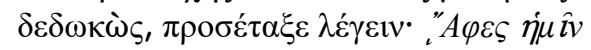
$\tau \dot{\alpha} \dot{o} \varphi \varepsilon \imath \lambda \dot{\eta} \mu \alpha \tau \alpha \dot{\eta} \mu \hat{\omega} v, \dot{\omega} \varsigma \kappa \alpha \dot{\imath} \dot{\eta} \mu \varepsilon \hat{i} \varsigma \dot{\alpha} \varphi i^{\prime}$

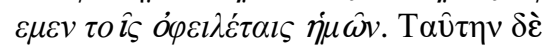

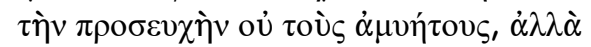

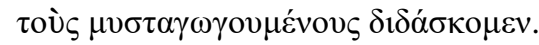

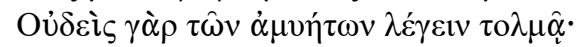

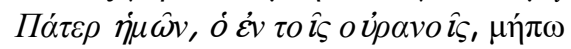

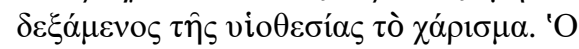
$\delta \grave{\varepsilon} \tau \hat{\eta} \varsigma \tau o \hat{v} \beta \alpha \pi \tau i ́ \sigma \mu \alpha \tau \sigma \varsigma \tau \varepsilon \tau v \chi \eta \kappa \hat{\omega} \varsigma \delta \omega-$

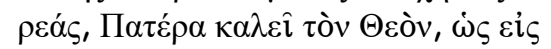

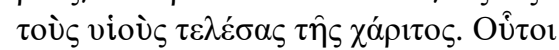

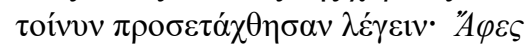
$\dot{\eta} \mu \hat{\imath} v \tau \dot{\alpha} \dot{o} \varphi \varepsilon \imath \lambda \dot{\eta} \mu \alpha \tau \alpha \dot{\eta} \mu \hat{\omega} v$.

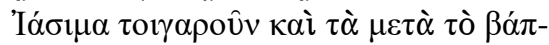

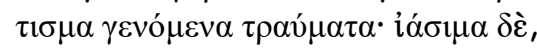

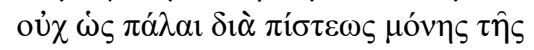

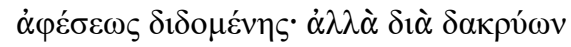

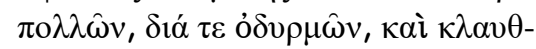

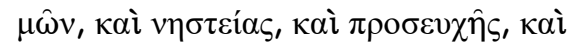

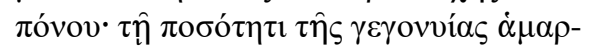

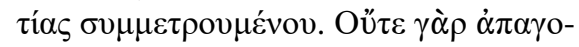

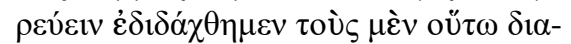

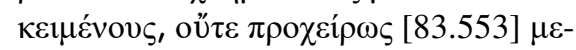

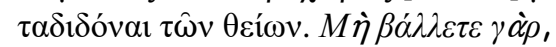

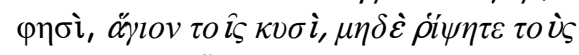

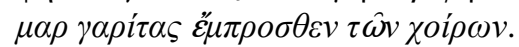

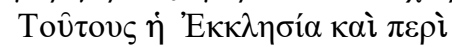

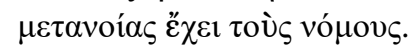

offering healing to him and to his brethren. Scilicet he said: "and when you have turned back, strengthen your brothers".

Giving the model of the prayer to the apostle, the Lord ordained them to say: "And forgive us our debts, as we also have forgiven our debtors". We do not teach this prayer the outsiders but only the insiders. No outsider should dare to say "our Father, who are in heaven", only the ones who received the gift of the 'sonship'. Everybody who received the gift of baptism could call God as Father, as [result] of the perfect grace toward God's children. To them the Lord commended to say: "forgive us our debts".

Therefore, curable are the wounds that happened after the baptism, too. But the curability is not given only through the former faith in forgiveness but also through many tears; through lamentations, weeping, fasting, prayer and hard work - measured accordingly to the quantity of the committed sins. We did not learn on the one hand to forbid people in such situation, but on the other hand we should not give easily up the divine [things]. It is said: "Do not give dogs what is sacred; do not throw your pearls to pigs".

The Church has these laws concerning repetance.

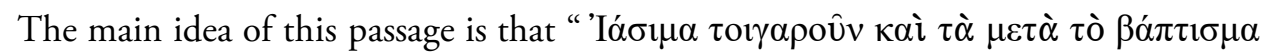
$\gamma \varepsilon v o ́ \mu \varepsilon v \alpha \tau \rho \alpha v ́ \mu \alpha \tau \alpha$ ”. In a very detailed argumentation, Theodoret wants to show on the one hand that there is a possibility for the remission of sins after baptism as well, but on the other hand, it is not too easy to acquire it. This approach can be deemed evidently as the following step in the evolution of the relation between the remission of sins and baptism. Let us take the Shepherd of Hermas as an example which seems to proclaim the possibility of a once-only post-baptismal forgiveness of sins. Drobner mentions in his introduction to the Church Fathers that according to some researchers (Windisch, Dibelius, and others) prior to Hermas, there was no possibility of a second 
repentance after baptism. ${ }^{412}$ But, because of the daily experience of sinfulness (in the life of baptized Christians as well), the Shepherd of Hermas and many other writers open a new opportunity to repent. ${ }^{413}$ We find the following statement in the aforementioned book of Drobner:

The subsequent history of repentance in the early church demonstrates that in the case of grave sins it was indeed practice, until the fifth century, to allow only one postbaptismal opportunity to repent in public. The imposed works of repentance became so severe, such as the lifelong renunciation of sexual intimacy in marriage, that repentance was increasingly deferred until the end of life; indeed the Gallic synods barred younger individuals from repentance. Only beginning with the fifth century did the Irish-Scottish mission introduce the development of unlimited private and repeated repentance in the Latin church on the continent. ${ }^{414}$

It is not clear whether Drobner refers to the universal Church or only to the churches of the West. But its analysis - because of the complexity of the question - could be the subject of another research. Here I quoted a passage from Drobner's book only to illustrate the steps of evolution of the approach to the post-baptismal opportunity of repentance. Based on the text of Theodoret, I think that there existed the possibility of the post-baptismal repentance in the Eastern Churches of the $5^{\text {th }}$ century, which must have been shown through the imposed works. Some heretic communities (like the Novatians) denied this possibility from the members of their communities.

In the chapter concerning repentance, the question of the post-baptismal remission of sins is linked to the $5^{\text {th }}$ demand of the Lord's Prayer. Theodoret underlines that the Lord's Prayer was the material either of the post-baptismal catechesis or of the cateche-

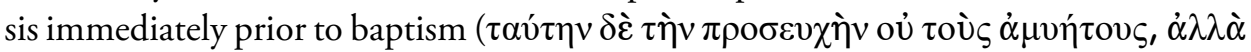

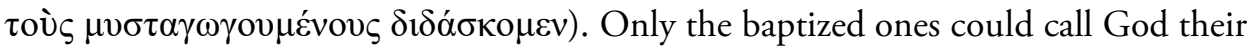
Father because they received the gift of the Holy Spirit and that of the sonship (adoption) through baptism and they could enjoy a perfect grace in this new relationship.

This passage is a bright evidence of Theodoret taking the human weakness and the fallibility of the human nature into account. It is not possible to detect the causes of the human weakness from this text of Theodoret, but based on the imposed works of the repentance, we can conclude that similarly to Chrysostom, he saw the main cause of actual sins in the indifference towards God. In the case of our topic, it is important to see that according to Theodoret, there exists the possibility of healing from indifference - not simply through faith and remission but through all the works of the repentance as: many tears, lamentations, weeping, fasting, prayer and hard work, measured

412 Drobner, Hubertus: The Fathers of the Church. A comprehensive Introduction. Hendrickson Publishers, Peabody MA 2007. 41.

413 Drobner, Hubertus: The Fathers of the Church. A comprehensive Introduction. 41.

414 Drobner, Hubertus: The Fathers of the Church. A comprehensive Introduction. 42. 
accordingly to the quantity of the committed sins. According to the position of the theological school of Antioch, the role of these works is first of all not to "buy the divine favor" but to strengthen the enthusiasm and the willingness, eagerness, or zeal (with the adequate Greek word, which has 868 occurrences in Chrysostom's writings and 152 in those of Theodoret: the $\pi \rho \circ \theta v \mu i$ í ) towards God.

\section{THE PRACTICE OF BAPTISM IN THE CHAPTERS RELATED TO THE DESCRIPTION OF HERESIES}

In his HFC, Theodoret presents not only the orthodox theology and practice of baptism but in several chapters of books $1-4$ of the HFC, speaking about different heretics, he presents also how they distort the doctrine and practice of the all-holy baptism. First, let us see the overview of these passages:

\begin{tabular}{|c|c|c|}
\hline Passage in the HFC: & Passage in Migne PG: & Title of the chapter: \\
\hline HFC 1,2 & $83: 345,36-43$ & 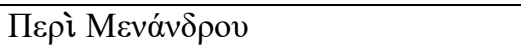 \\
\hline HFC 1,9 & $83: 360,12-19$ & 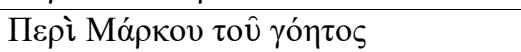 \\
\hline HFC 1,10 & $83: 360,29-36$ & 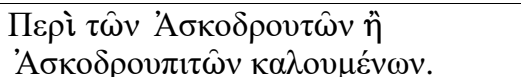 \\
\hline HFC 2,7 & $83: 393,19-27$ & 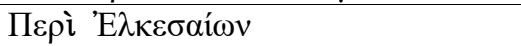 \\
\hline HFC 3,5 & $83: 408,23-31$ & 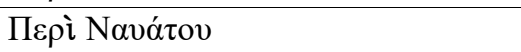 \\
\hline HFC 4,1 & $83: 413,18-41$ & 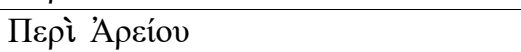 \\
\hline HFC 4,3 & $83: 420,23-48$ & 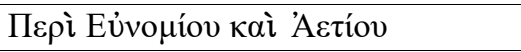 \\
\hline HFC 4,11 & $83: 429,28-432,3$ & 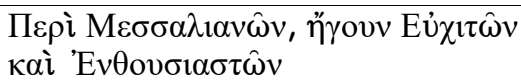 \\
\hline
\end{tabular}

Ferguson writes in his monograph that "Theodoret describes these practices because they departed from the church's usual manner of administering baptism" ${ }^{415}$ Although Ferguson asserts it after quoting Theodoret's presentation concerning the aberration of the Eunomians, I think this statement is true in all cases of the heretic misuses of the holy baptism presented by Theodoret. Ferguson mentions furthermore that "the accuracy of the reports" and "the frequency of what is decribed" may be questioned. ${ }^{416}$

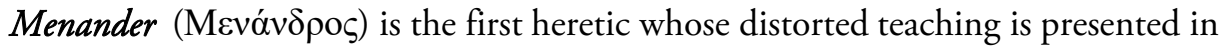
relation to baptism. Theodoret describes his ideas on baptism as follows:

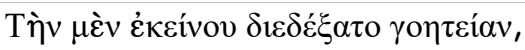

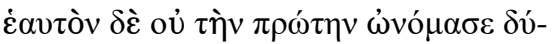
$\nu \alpha \mu \mathrm{v} \cdot \ddot{\alpha} \gamma \nu \omega \sigma \tau \sigma \nu \gamma \grave{\alpha} \rho \ddot{\varepsilon} \varphi \eta \sigma \varepsilon \tau \alpha \hat{v} \tau \eta v \cdot$
He followed the cheatery of that [i.e., of Simon], but he did not call himself the first power, because he taught it to be unknown.

415 Ferguson, Everett: Baptism in the Early Church. Eerdmans, Grand Rapids 2009. 716.

416 Ferguson, Everett: Baptism in the Early Church. Eerdmans, Grand Rapids 2009. 716. 
$\dot{\alpha} \lambda \lambda^{\prime}$ نं $\pi^{\prime} \dot{\varepsilon} \kappa \varepsilon i ́ v \eta \varsigma \dot{\alpha} \pi \varepsilon \sigma \tau \alpha \dot{\lambda} \theta \alpha \mathrm{\alpha} \beta \rho \varepsilon v \theta v o ́-$ $\mu \varepsilon v o \varsigma \Sigma \omega \tau \hat{\eta} \rho \alpha \dot{\varepsilon} \alpha v \tau o ̀ v ~ \pi \rho \circ \sigma \eta \gamma o ́ \rho \varepsilon v \sigma \varepsilon$,

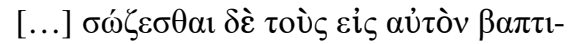

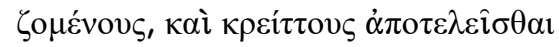

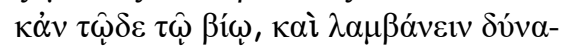

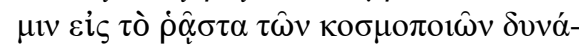

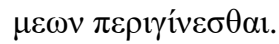

But he saw himself haughtily to be the Saviour sent by that. [...] [According to him] only those will be saved who are baptized into his name. Furthermore, they will become more excellent in this life and they will receive power to become the most easily of the world-creating powers.

Other sources report that he considered the water of baptism the source of perpetual youth. ${ }^{417}$ I think this conclusion of scholars can be explained through Theodoret's text

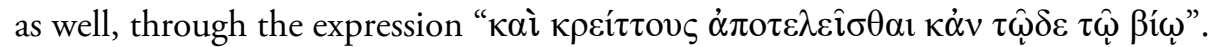

In the chapter about Mark the sorcerer, we read the following information concerning the practice of baptism:

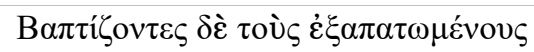

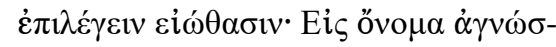

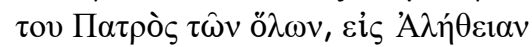

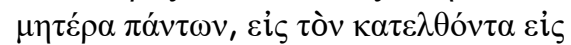

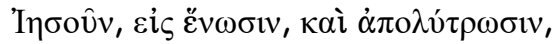

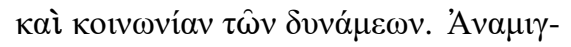

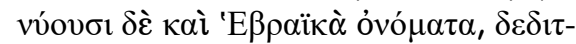

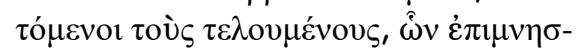

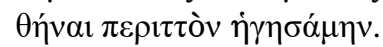
They baptize the deceived ones, using to say upon them: in the name of the unknown Father of the universe, into the Truth, the mother of all, into the one who came down, into Jesus, and the unity, and salvation and the communion of the powers. They mix the Hebrew names also, frightening the ac- complished [initiated] ones, for whom it is beyond normal to remember all these.

We can recognize some gnosticizing elements in this description and according to Theodoret, they developed a cultic language which seemed to contain a mixture of the

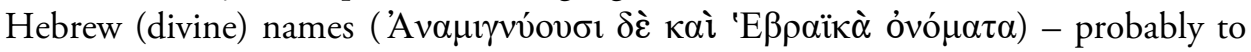
create the impression of a magical effect through them.

In the chapter about the heresy of the Ascodrutes we read that they did not practice baptism because of their philosophical teaching. As they deemed salvation to be spiritual, they rejected the practice of baptism as corporeal, replacing it with the true and

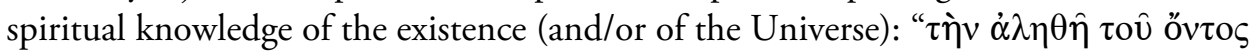

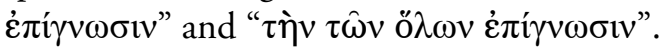

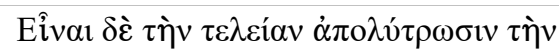

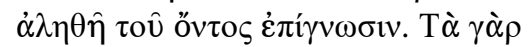

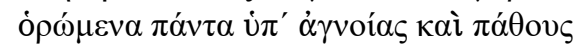

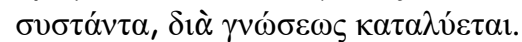

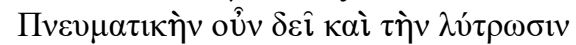

They say the perfect salvation to be the true knowledge of the existence. Every visible thing, subjected to ignorance and suffering, will be liberated through knowledge. In this way the salvation also

417 Grant, Robert M: Augustus to Constantine: The Rise and Triumph of Christianity in the Roman World. Westminster John Knox Press, London 2004. 123. 


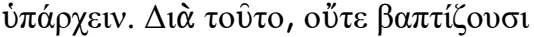

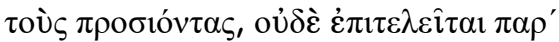

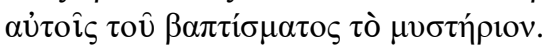

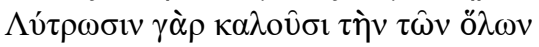

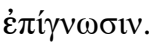

must be spiritual. Therefore they either do not baptize those who join to them, nor in their communities do not accomplish the mystery of baptism. They say namely, that salvation is the knowledge of the universe.

The following presentation of their baptismal practices is to be found in the chapter concerning the heresy of the Elkesaites:

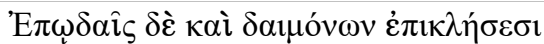

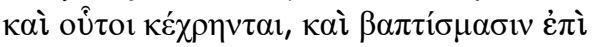

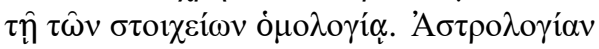

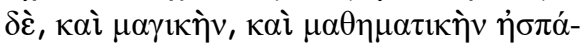

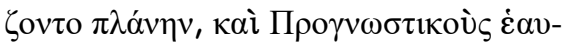

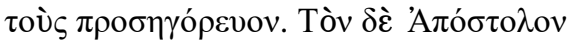

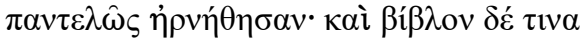

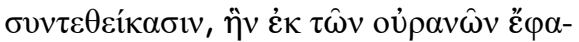

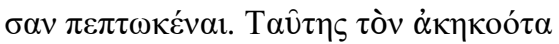

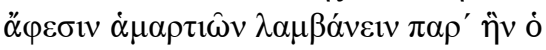
X
They use incantations and the invocation of demons, and they baptize upon the confession of the elements. They prefer the aberration of the astrology, magic and mathematics, and they call themselves prognostics. They deny totally the Apostle and they composed a book which they say to be fallen from the heaven. Who obey to this [book], will gain the remission of sins, beside that which is given as present by Christ.

In the writings of Hippolyt of Rome, there is a much more detailed description of Elkesaites's baptismal practice which can explain what Theodoret briefly summarizes. According to Hippolyt, baptism is administrated among these heretics using the following words:

If, therefore, (my) children, one shall have intercourse with any sort of animal whatsoever, or a male, or a sister, or a daughter, or has committed adultery, or been guilty of fornication, and is desirous of obtaining remission of sins, from the moment that he hearkens to this book let him be baptized a second time in the name of the Great and Most High God, and in the name of His Son, the Mighty King. And by baptism let him be purified and cleansed, and let him adjure for himself those seven witnesses that have been described in this book - the heaven, and the water, and the holy spirits, and the angels of prayer, and the oil, and the salt, and the earth. ${ }^{418}$

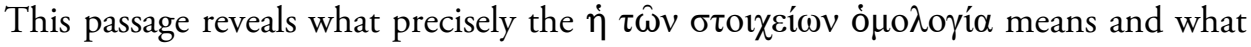
these elements are. Theodoret briefly mentions what is more detailed in Hipplolyt's text: only those will be baptized and will receive the remission of sins who obey the Book of Elkesai/Elchesai/Elchasai. From what Theodoret writes about the affection for 
magic of the Elkesaites, it can be concluded from the text of Hippolyt that they attributed a magic-therapeutic effect to the baptismal bath: ${ }^{419}$

But since we have stated that these resort to incantations for those bitten by dogs and for other mishaps, we shall explain these. Now Elchasai uses the following formulary: If a dog rabid and furious, in which inheres a spirit of destruction, bite any man, or woman, or youth, or girl, or may worry or touch them, in the same hour let such a one run with all their wearing apparel, and go down to a river or to a fountain wherever there is a deep spot. Let (him or her) be dipped with all their wearing apparel, and offer supplication to the Great and Most High God in faith of heart, and then let him thus adjure the seven witnesses described in this book: 'Behold, I call to witness the heaven and the water, and the holy spirits, and the angels of prayer, and the oil, and the salt, and the earth. I testify by these seven witnesses that no more shall I sin, nor commit adultery, nor steal, nor be guilty of injustice, nor be covetous, nor be actuated by hatred, nor be scornful, nor shall I take pleasure in any wicked deeds.' Having uttered, therefore, these words, let such a one be baptized with the entire of his wearing apparel in the name of the Mighty and Most High God. ${ }^{420}$

We find information about the post-baptismal liturgical actions in the chapter about the heresy of the Novatians:

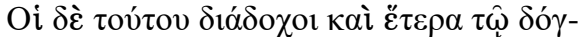

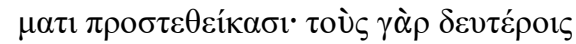

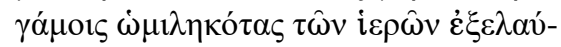

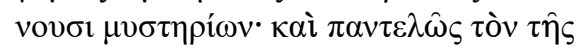

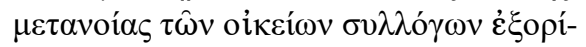

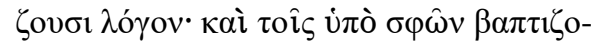

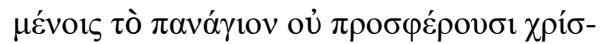

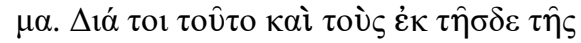

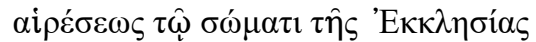

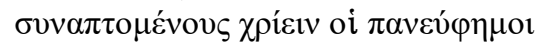

$$
\begin{aligned}
& \Pi \alpha \tau \varepsilon \dot{\rho} \varepsilon \varsigma \pi \rho \circ \sigma \varepsilon ́ \tau \alpha \xi \alpha \nu \text {. }
\end{aligned}
$$

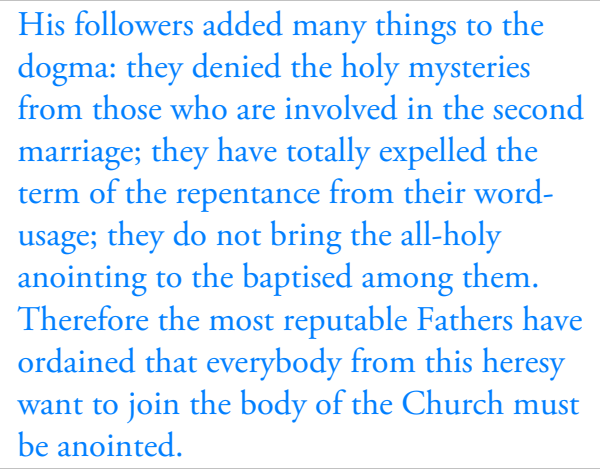

His followers added many things to the dogma: they denied the holy mysteries from those who are involved in the second marriage; they have totally expelled the term of the repentance from their wordusage; they do not bring the all-holy anointing to the baptised among them. Therefore the most reputable Fathers have ordained that everybody from this heresy want to join the body of the Church must be anointed.

This is the only passage in the whole HFC where we find technical terms related to the liturgical actions around baptism other than the words originating from the root $\beta \alpha \pi \tau$. Here the author writes about the $\pi \alpha \nu \alpha$ $\gamma$ lov $\chi \rho i \sigma \mu \alpha$. If Theodoret's perception of postbaptismal anointing matches that of the writer of the Apostolic Constitutions - as J. Ysebaert states $\mathrm{it}^{421}$ - then it seems to be "a confirmation of the confession" and "a

419 Ysebaert, Joseph: Greek baptismal terminology: its origins and early development. 81.

420 Hippolyt of Rome: Refutation of all heresies (Book 9, chapter 10).

see: http://www.newadvent.org/fathers/050109.htm (opened: 2015-05-03)

421 Ysebaert, Joseph: Greek baptismal terminology: its origins and early development. 363. 
seal of the contracts". Theodoret compares the pre- and the post-baptismal anointing in his Eranistes: this way, the pre-baptismal anointing is administered in order to become Christians, while in the Syrian Church, the post-baptismal anointing is considered the rite which confers the Holy Spirit. ${ }^{422}$ In the Eranistes -Ysebaert says - Theodoret was not able to indicate clearly the meaning of the post-baptismal anointing "as the rite by which the Spirit is conferred". He states only that it is a reminder of Christ's sepulture. ${ }^{423}$ In Theodoret's theological system, the gift of the Spirit is connected to the baptismal imposition of hands, ${ }^{424}$ but there is a passage in his commentary to the Song of Songs where anointing with " $\mu$ v́pov" confers the grace of the Spirit. ${ }^{425}$

Theodoret criticize the Novatians on the one hand that they deny people who - according to them - have graver sins of the sacrament of baptism, and on the other hand that they suppress the post-baptismal rites and do not practice the post-baptismal anointing. Ysebaert quotes Eusebius of Caesarea, according to whom "they may have done so since Novatian himself did not receive this rite" ${ }^{426}$ Ysebaert - in accordance with the Ferguson's opinion that Theodoret's information concerning the heretica are not always accurate - asserts that Theodoret

may quite simply have drawn the wrong conclusion from the existing practice of anointing the Novatian converts and from the explanation as it was put forward by Didymus the Blind for the anointing of all heretics. ${ }^{427}$

Furthermore, Ysebaert underlines that the imposition of the hands and the anointing do not repeat the rites already received but they are intended to restore them, and are thus reconciliation rites. ${ }^{428}$

In the chapter concerning Arius we read the following presentation of his approach to baptism:

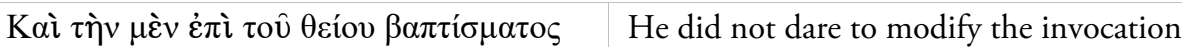

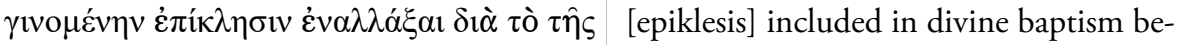

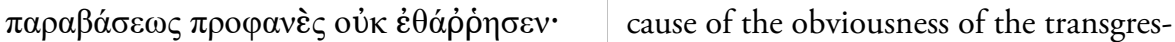

422 Ysebaert, Joseph: Greek baptismal terminology: its origins and early development. 318. Ysebaert remarks that the terminology of the pre- and the post-baptismal anointing is different. The pre-bap-

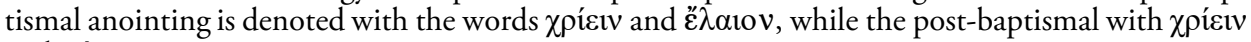
and $\mu$ ópov.

423 Ysebaert, Joseph: Greek baptismal terminology: its origins and early development. 364.

424 Ysebaert, Joseph: Greek baptismal terminology: its origins and early development. 383.

425 Ysebaert, Joseph: Greek baptismal terminology: its origins and early development. 364.

426 Ysebaert, Joseph: Greek baptismal terminology: its origins and early development. Dekker \& van de Vegt, Nijmegen 1962. 338.

427 Ysebaert, Joseph: Greek baptismal terminology: its origins and early development. 338.

428 Ysebaert, Joseph: Greek baptismal terminology: its origins and early development. 338. 


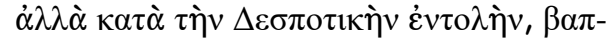

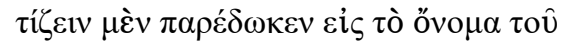

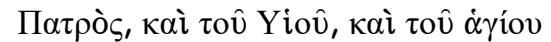

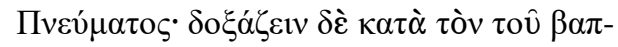

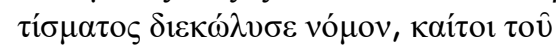

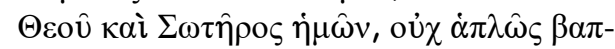

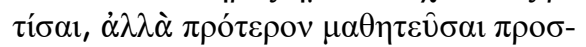

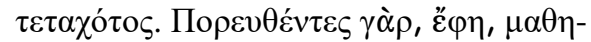

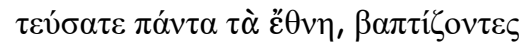

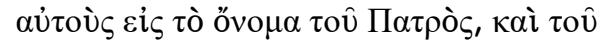

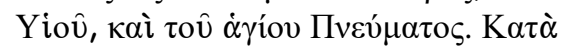

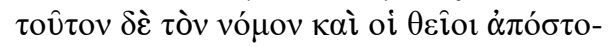

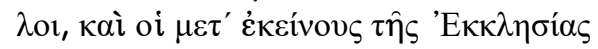

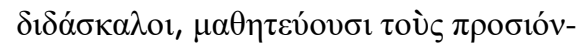

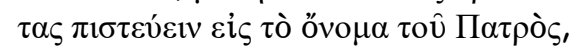

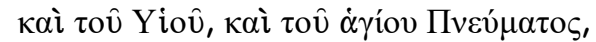

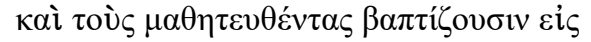

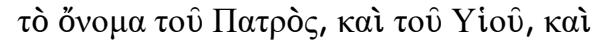

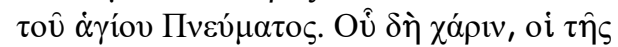
$\delta \omega \rho \varepsilon \alpha \dot{\varsigma} \dot{\alpha} \pi \mathrm{\alpha} \lambda \alpha v ́ \sigma \alpha v \tau \varepsilon \varsigma, \dot{\omega} \varsigma \dot{\varepsilon} \mu \alpha \theta \eta \tau \varepsilon v ́ \theta \eta-$

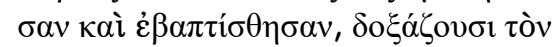

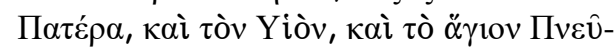
$\mu \alpha \Sigma \chi \dot{\varepsilon} \tau \lambda$ tov $\gamma \grave{\alpha} \rho, \tau$ ò̀ $\varsigma \alpha \rho \grave{\alpha} \tau \hat{\eta} \varsigma \dot{\alpha} \gamma i ́ \alpha \varsigma$

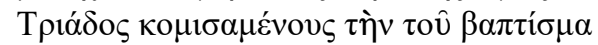

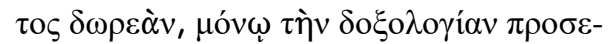

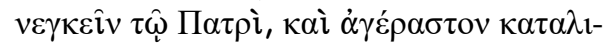

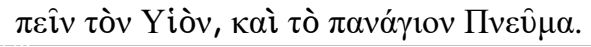

sion, but according to the Ruler's commandment he handed over [i.e. taught] baptism into the name of the Father and of the Son and of the Holy Spirit. Yet he banned the doxology according to the law of baptism, although our God and Saviour prescribed not simply baptism, but making disciples rst. For he says, 'Go, make disciples of all nations, baptising them into the name of the Father and of the Son and of the Holy Spirit' (Matt. 28:19). According to this law, both the divine apostles and the teachers of the church after them, instructed those who came forward to believe in the name of the Father and of the Son and of the Holy Spirit and they baptised those who were made disciples into the name of the Father and of the Son and of the Holy Spirit. This is why indeed those who bene ted from the gift in the sense that they were made disciples and baptised, glorify the Father and the Son and the Holy Spirit. It is abominable for those who were granted the gift of baptism from the Holy Trinity to offer doxology only to the Father and to leave the Son and the All-holy Spirit unhonoured. ${ }^{429}$

Here Theodoret objects to Arius that "he banned the doxology according to the law of baptism", offering doxology "only to the Father" and leaving "the Son and the Allholy Spirit unhonoured”. After reading the passage concerning Arius's approach to baptism, we will have the impression that Theodoret accuses him not only of corrupting the baptismal doxology but of hypocrisy as well. The motif of Arius' hypocrisy comes forth in many ancient Christian writings, in the most emphatical way probably in the Historia ecclesiastica of Socrates Scholasticus (e.g., HE 1,26; 1,38).

About the misuse of baptism through Eunomius and his followers we read:

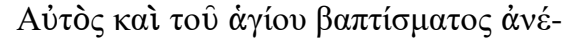

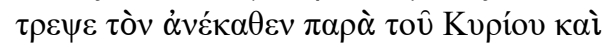

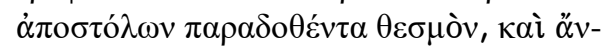

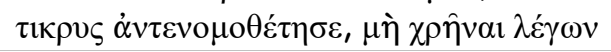

He overthrew even the ordinance of holy baptism, which had been handed down of old by the Lord and the apostles, and openly made contrary laws, saying that it 


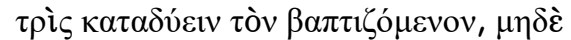

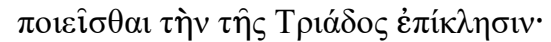

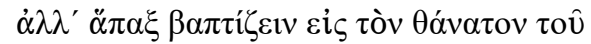

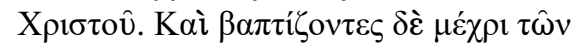

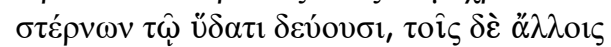

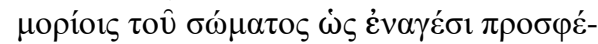

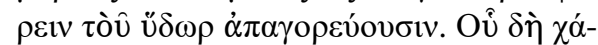

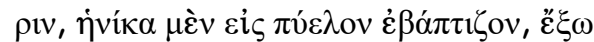

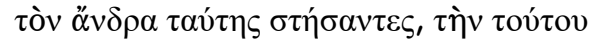

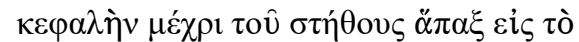

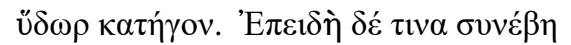
$\tau \rho \alpha v \mu \alpha \tau i \alpha v \gamma \varepsilon v \varepsilon \varepsilon^{\prime} \sigma \alpha l \tau \hat{\eta} \varsigma \kappa \varepsilon \varphi \alpha \lambda \hat{\eta} \varsigma \tau \hat{\eta} \pi v \varepsilon \varepsilon^{-}$

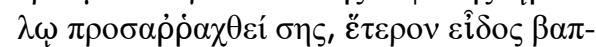

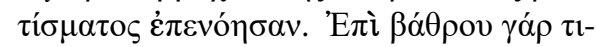

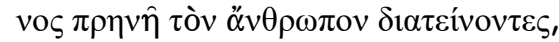

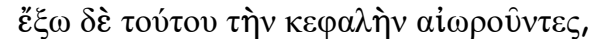

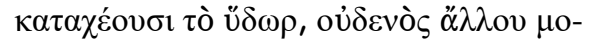

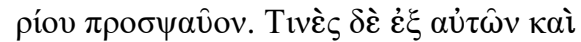

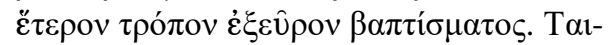

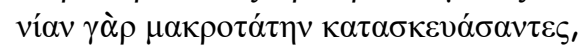

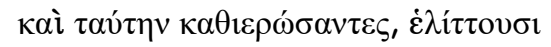

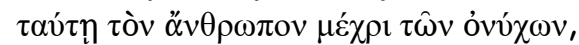

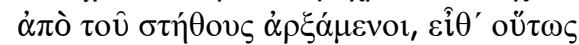

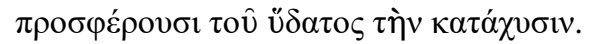

was necessary neither to immerse the baptised three times, nor to perform the invocation of the Trinity, but rather to baptise once into the death of Christ. When baptising they drench with water as far as the chest, yet they forbid applying water to the other members of the body, [considering these] as accursed. This is why they baptise in a tub with the man standing outside of it, and lower his head down once as far as his chest into the water. Yet since it happened that someone was injured on the head as it struck the tub, they contrived another form of baptism: they stretch a person out head-rst on a bench, raise his head from this, and pour water on it while not touching any other member [of the body]. Some of them, however, invented yet another mode of baptism. They prepare and consecrate a very long band [of cloth] and wind it around the man as far as his finger-tips, beginning from the chest, then they perform the pouring of water in this manner. ${ }^{430}$

In this description, we can find both elements of the orthodox baptismal practice (the three immersions, the invocation of the Trinity) and the distorted practice through the heretics. Theodoret characterizes the distortion of baptism through Eunomius as

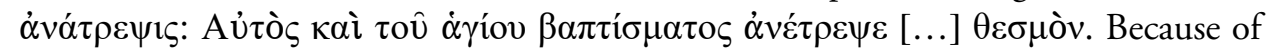

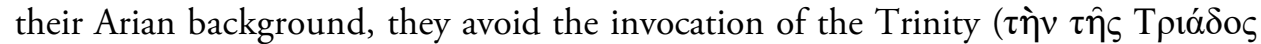

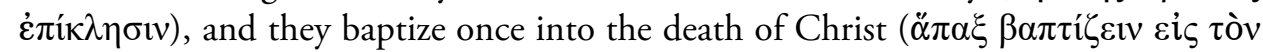

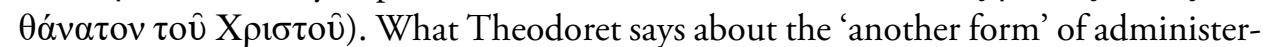
ing of the sacrament appears - according to Ferguson - as a parody of orthodox baptism. ${ }^{431}$ The submersion happens with the head forward and only the upper body will be soaked. He deemed that the other body parts are not worthy to be baptized. Accord-

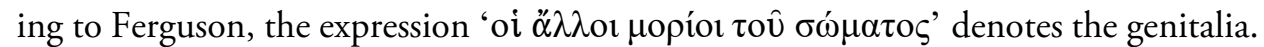

There is a similar passage about the Eunomian baptismal practice in the 'Panarion' of Epiphanius which provides us with some auxiliary information:

430 Pásztori-Kupán István: Theodoret of Cyrus. Routledge, London 2006. 217.

431 Ferguson, Everett: Baptism in the Early Church. Eerdmans, Grand Rapids 2009. 716. 


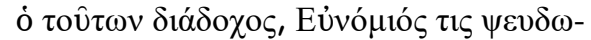

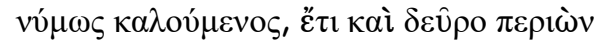

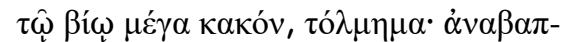

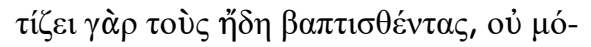

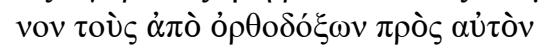

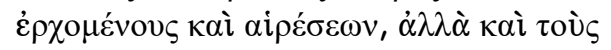

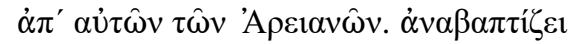

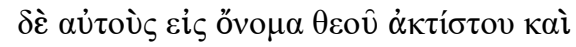

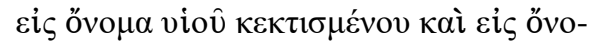
$\mu \alpha \pi v \varepsilon v ́ \mu \alpha \tau o \varsigma \dot{\alpha} \gamma 1 \alpha \sigma \tau$

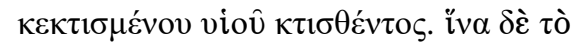

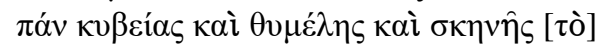

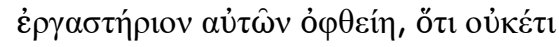

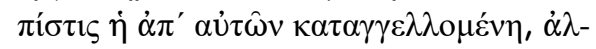
$\lambda \grave{\alpha} \sigma \chi \varepsilon \delta o ̀ v ~ \varepsilon i \pi \varepsilon \hat{\imath} v \mu i ́ \mu \omega v \dot{\varepsilon} \rho \gamma \alpha \sigma \tau \eta ́ p t o v, \delta i \varepsilon-$

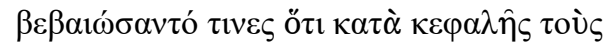

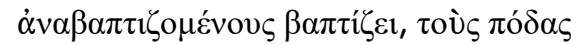

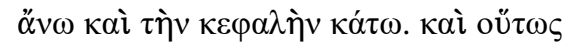

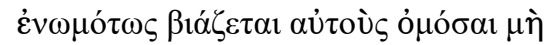
$\dot{\alpha} \pi \mathrm{o} \pi \eta \delta \dot{\sigma} \sigma \alpha \mathrm{\imath} \tau \hat{\eta} \varsigma \dot{\alpha} \pi^{\prime} \alpha \dot{\tau} \tau \mathrm{v} \hat{\mu} \mu \mu \eta \chi \alpha \nu \eta \mu \varepsilon^{-}$

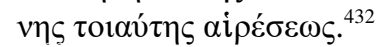

(32) $[\ldots]$ a person miscalled Eunomius (i.e., "law-abiding"), who is still alive to be a great evil, and introduces another piece of impudence. For he rebaptizes persons already baptized - not only people who come to him from the orthodox and the sects, but even from the Arians. (33) $\mathrm{He}$, however, rebaptizes them in the name of God the Uncreated, and in the name of the Created Son, and in the name of the Sanctifying Spirit created by the Created Son. (34) And to make it clear that it is no longer faith which their whole workshop of jugglery, theater and farce proclaims, but practically clowns' work, some maintain that he baptizes his candidates for rebaptism upside down, with their feet on top and their heads below. (35) And while they are in this position he obliges them to swear an oath that they will not abandon the sect he has cooked up. ${ }^{433}$

The last chapter where we can read about the misuse of baptism is about the heresy of the Messalians .

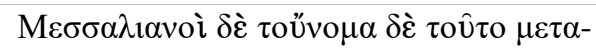

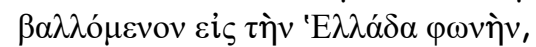

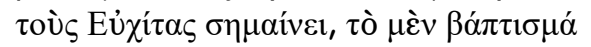

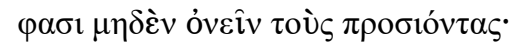

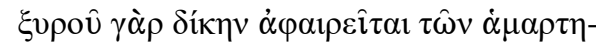

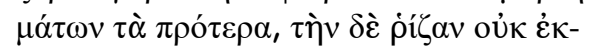

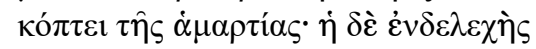

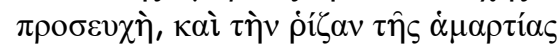

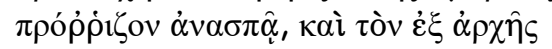

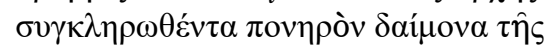

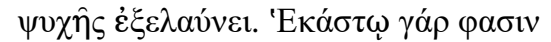

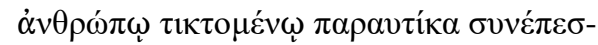

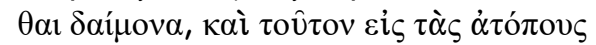

The name of the messalians means in Greek translation Euchithes. They assert on the one hand that baptism uses fot nothing in the life of those who receive it, because like the razor of the justice it clears away the sins of the past, but it does not cut out the root of $\sin$. On the other hand they say that the continuous prayer is which cuts off the root of the sin and drives out the evil demon of the soul, which was inherited from the beginning. They say that this demon attacks every human directly in the moment of birth, and compelles them to incongruous

432 Epiphanius von Salamis: Panarion. In: Holl, K. (ed.): Epiphanius, Bände 1-3: Ancoratus und Panarion. Band 3. Hinrichs, Leipzig 1933. 413-14.

433 Epiphanius of Salamis: Panarion. In: Williams, Frank (tr.): The Panarion of Epiphanius of Salamis, Books II and III. De fide. BRILL, Leiden 2013. 579-80. 


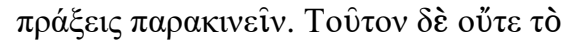

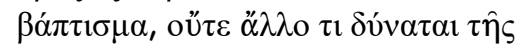
$\psi v \chi \eta \hat{\jmath} \varsigma \dot{\varepsilon} \xi \varepsilon \lambda \alpha ́ \sigma \alpha 1, \dot{\alpha} \lambda \lambda \dot{\alpha} \mu o ́ v \eta \tau \hat{\eta} \varsigma \pi \rho o \sigma \varepsilon v-$

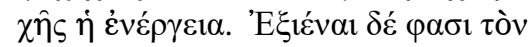

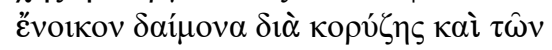

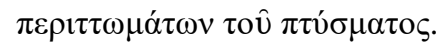

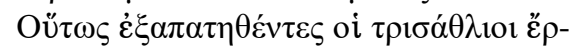

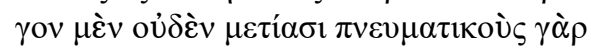

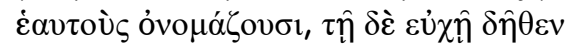

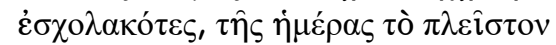
$\kappa \alpha \theta \varepsilon v ́ \delta$ ovøıv.

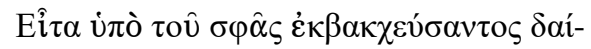

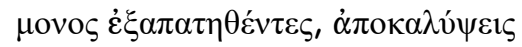

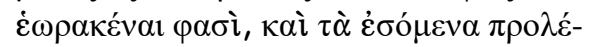

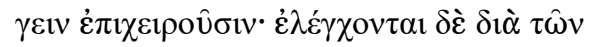

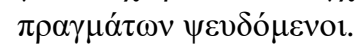

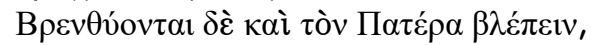

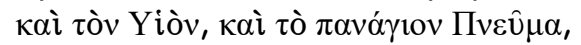

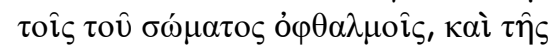

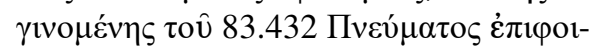

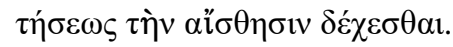

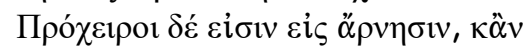

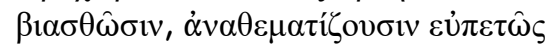

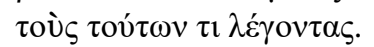

deeds. This demon could not be driven out from the soul either through baptism or anything else, but only though the power of the prayer. They say that the demon goes out from the through the run of the nose and through sputum.

In this way these thrice miserable deceived ones on the one hand do not do anything, because they call themselves spiritual people. On the other hand they really having leisure in prayer, they slumber away the golden hours.

Further, deluded by this fool demon, they say they see relvelations, and they try to forecast the future - but the events contradict to these liars.

They brazen that they have seen with their corporeal eyes the Father, the Son and the All-holy Spirit and that they have received the ability to detect the future coming of the Spirit.

They are ready to betrayal and browbeating, and they anathematize easily those who reveal anything of these.

After quoting passages from this chapter, Otmar Hesse summarizes the teaching of Messalians with the following words:

Die Taufe gewährt keinen Nutzen, sie entfernt wie ein Rasiermesser die früheren Sünden, der Dämon begleitet seit Geburt jeden Menschen, nur das eifrige Gebet kann ihn aus der Seele vertreiben. ${ }^{434}$

Hubertus Drobner, presenting the work of Simeon of Mesopotamia (Macarius), summarizes the Messalians' approach to baptism and their thoughts concerning its role and effect with the following words:

In agreement with the theology of the church at large, he assumes that all human sin is predicated upon original sin. Unlike the common theology of the church, however, he does not acknowledge that this inherited debt is cleansed in baptism, but merely recognizes the latter as the beginning of the spiritual battle against evil, in which the grace of the Spirit

434 Hesse, Otmar: Der Streit über die Wirkung der Taufe im frühen Mönchtum. In: Hellholm, David - Vegge, Tor - Norderval, Øyvind - Hellholm, Christer (eds.): Ablution, Initiation, and Baptism. Late Antiquity, Early Judaism, and Early Christianity. De Gruyter, Berlin 2011. 1334. 
has to be gained more and more, for the latter renews the image of God in the human person. Hence, for him, the virtue surpassing all others and on which all others depend is prayer; in the ideal case, this becomes constant prayer. This means, however, that redemption does not primarily result from Christ's sacrifice and from participating in it in the sacrament of baptism, but from success in the battle of prayer and from gaining through it the grace of the Spirit on the basis of an individual's effort. ${ }^{435}$

Theodoret mentions the teaching concerning baptism of the Messalians is his Historia ecclesiastica as well, but we find there supplementary information on how the Holy Spirit comes to take the place of the outdriven demon: ${ }^{436}$

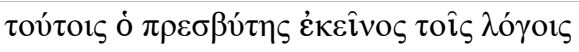

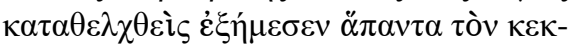

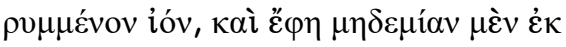

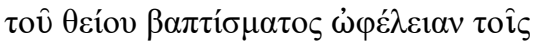

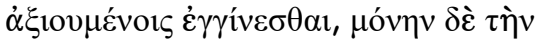

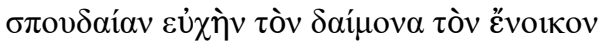

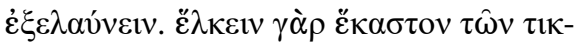

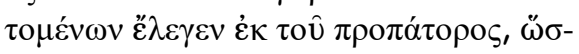

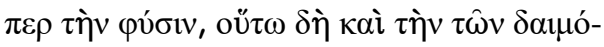

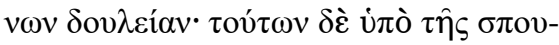

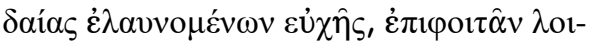

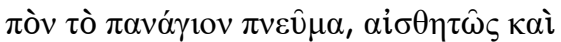

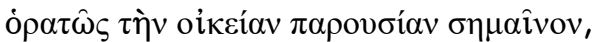

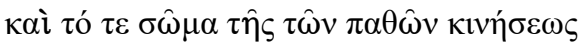

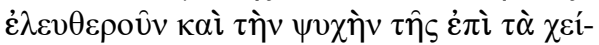
$\rho \omega \dot{\rho} 0 \pi \hat{\eta} \varsigma \pi \alpha v \tau \varepsilon \lambda \hat{\omega} \varsigma \dot{\alpha} \pi \alpha \lambda \lambda \alpha \dot{\alpha} \tau \tau \varepsilon v v, \dot{\omega} \varsigma \mu \eta-$

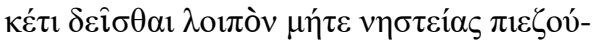

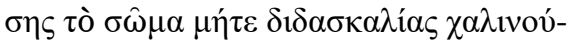

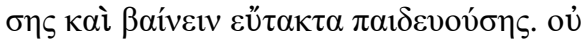

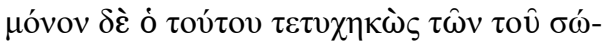

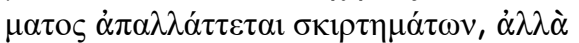

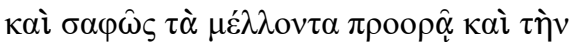

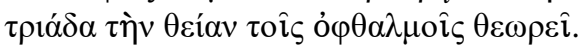

The old man was won over by these words and gave vent to all his secret venom, for he said that no benefit accrues to the recipients of Holy Baptism, and that it is only by earnest prayer that the in-dwelling demon is driven out, for that every one born into the world derives from his first father slavery to the demons just as he does his nature; but that when these are driven away, then come the Holy Ghost giving sensible and visible signs of His presence, at once freeing the body from the impulse of the passions and wholly ridding the soul of its inclination to the worse; with the result that there is no more need for fasting that restrains the body, nor of teaching or training that bridles it and instructs it how to walk aright. And not only is the recipient of this gift liberated from the wanton motions of the body, but also clearly foresees things to come, and with the eyes beholds the Holy Trinity. (HE 4,10) ${ }^{437}$

$$
\text { ***** } *
$$

435 Drobner, Hubertus: The Fathers of the Church. A comprehensive Introduction. 371.

436 Theodoret von Kyros: Kirchengeschichte. Akademie-Verlag, Berlin 1954. 231.

437 Theodoret of Cyrus: The ecclesiastical history. In: Schaff, Philip - Wace, Henry (eds.): Nicene and Post-Nicene Fathers, Second Series, Volume 3: Theodoret, Jerome, Gennadius and Rufinus: Historical writings. Cosimo, New York 2007 (The republication of the 1892 edition). 115. 
In the above presented chapters of the HFC, we got to know a great variety of baptismal practices and of approaches to baptism. These descriptions show us not only the opinions of orthodox theologians of the 'misuse' of the sacrament through heretics but in some cases, we get indirect references to the orthodox baptismal practice as well.

\section{CONCLUSION}

From the presentation above we learn that the HFC presents a multi-contextual image of the "all-holy" baptism. We saw that the divine origin of the sacrament determined Theodoret to offer it a special place within his theological system. This special place is expressed through the setting of the chapter concerning baptism as well: it is put between the soteriological Christology and the chapters concerning Theodoret's eschatology, the latter being an introduction to the ethical chapters. The chapter on baptism follows the chapter in which the author argues that both the Old and the New Testament are given by the same God, and it is followed by the chapter on the resurrection. This setting reveals Theodoret's ideas concerning its role (which was typical to the great teachers of the theological school of Antioch), which makes the main difference between the Western and the Eastern approach. Namely, while the Western approach emphasizes the remission of sins, the Eastern approach puts the main emphasis on the promise of eternal life. We can see in Theodoret's approach how both the remission of sins and the promise of eternal life are the two sides of the same coin: both of them are important, and they cannot be placed one above the other.

Furthermore, we can see that speaking about baptism appears not only as an independent topic but also embedded in the context of other topics. This way, the reader gains information on the soteriological, pneumatological, eschatological, ethical implications of the doctrine on baptism.

Beside theological grounding, we discover some information about the practice of baptism in West-Syria as well. We find information about the practice of infant baptism, about the manner of administering the sacrament (triple immersion), about the chain of sacramental actions (invocation of the Trinity, doxology, pre- and post-baptismal anointing), and questions of ecclesiastical diplomacy (in which condition the baptism of the heretics can be accepted - through the administration of the reconciling post-baptismal anointing).

This analysis opens the way to new researches. As the HFC is the last representative work of Theodoret, it would be interesting to analyse his approach to baptism within his opera omnia - but with special emphasis on the HFC. This way, the development of Theodoret's theological thinking concerning baptism could be monitorized, and compared with the life-experience of the author, the factors which determined the development of Theodoret's thinking can be revealed. 


\section{BIBLIOGRAPHY}

Drobner, Hubertus: The Fathers of the Church. A comprehensive Introduction. Hendrickson Publishers, Peabody MA 2007.

Epiphanius of Salamis: Panarion. In: Williams, Frank (tr.): The Panarion of Epiphanius of Salamis, Books II and III. De fide. BRILL, Leiden 2013.

Epiphanius von Salamis: Panarion. In: Holl, K. (ed.): Epiphanius, Bände 1-3: Ancoratus und Panarion. Band 3. Hinrichs, Leipzig 1933.

Ferguson, Everett: Baptism in the Early Church. Eerdmans, Grand Rapids 2009.

Grant, Robert M: Augustus to Constantine: The Rise and Triumph of Christianity in the Roman World. Westminster John Knox Press, London 2004.

Hartnup, Karen: 'On the Beliefs of the Greeks': Leo Allatios and Popular Orthodoxy. BRILL, Leiden 2004.

Hefele, Charles Joseph: A History of the Councils of the Church. tr. by William R. Clark, vol. 3. T. \& T. Clark, Edinburgh 1894-96.

Heim, Mark: The Depth of the Riches: A Trinitarian Theology of Religious Ends. Eerdmans, Grand Rapids 2001.

Hesse, Otmar: Der Streit über die Wirkung der Taufe im frühen Mönchtum. In: Hellholm, David - Vegge, Tor - Norderval, Øyvind - Hellholm, Christer (eds.): Ablution, Initiation, and Baptism. Late Antiquity, Early Judaism, and Early Christianity. De Gruyter, Berlin 2011.

Hippolyt of Rome: Refutation of all heresies (Book 9, chapter 10). see: http://www.newadvent.org/fathers/050109.htm (opened: 2015-05-03)

Meyendorff, John: Byzantine Theology: Historical Trends and Doctrinal Themes. Fordham University Press, 1979.

Pásztori-Kupán István: Theodoret of Cyrus. Routledge, London 2006.

Quasten, Johannes: Patrology III. The Golden Age of Greek Patristic Literature. Christian Classics, Allen (Texas) 1983.

Theodoret of Cyrus: Commentary on Psalms, 1-72 (Hill, Robert tr.). The Catholic University of America, Washington, D.C. 2000.

Theodoret of Cyrus: Commentary on Psalms, 73-150 (Hill, Robert tr.). The Catholic University of America, Washington, D.C. 2001.

Theodoret of Cyrus: The ecclesiastical history. In: Schaff, Philip - Wace, Henry (eds.): Nicene and Post-Nicene Fathers, Second Series, Volume 3: Theodoret, Jerome, Gennadius and Rufinus: Historical writings. Cosimo, New York 2007 (The republication of the 1892 edition).

Theodoret von Kyros: Kirchengeschichte. Akademie-Verlag, Berlin 1954.

Theodoretus Cyrensis: Haereticarum fabularum compendium. In: Migne PG 83,336-556.

Theodoretus Cyrensis: Interpretatio in Psalmos. In: Migne PG 80,1733

Ysebaert, Joseph: Greek baptismal terminology: its origins and early development. Dekker \& van de Vegt, Nijmegen 1962. 